Historic, Archive Document

Do not assume content reflects current scientific knowledge, policies, or practices. 
$62 x \cdot 61$

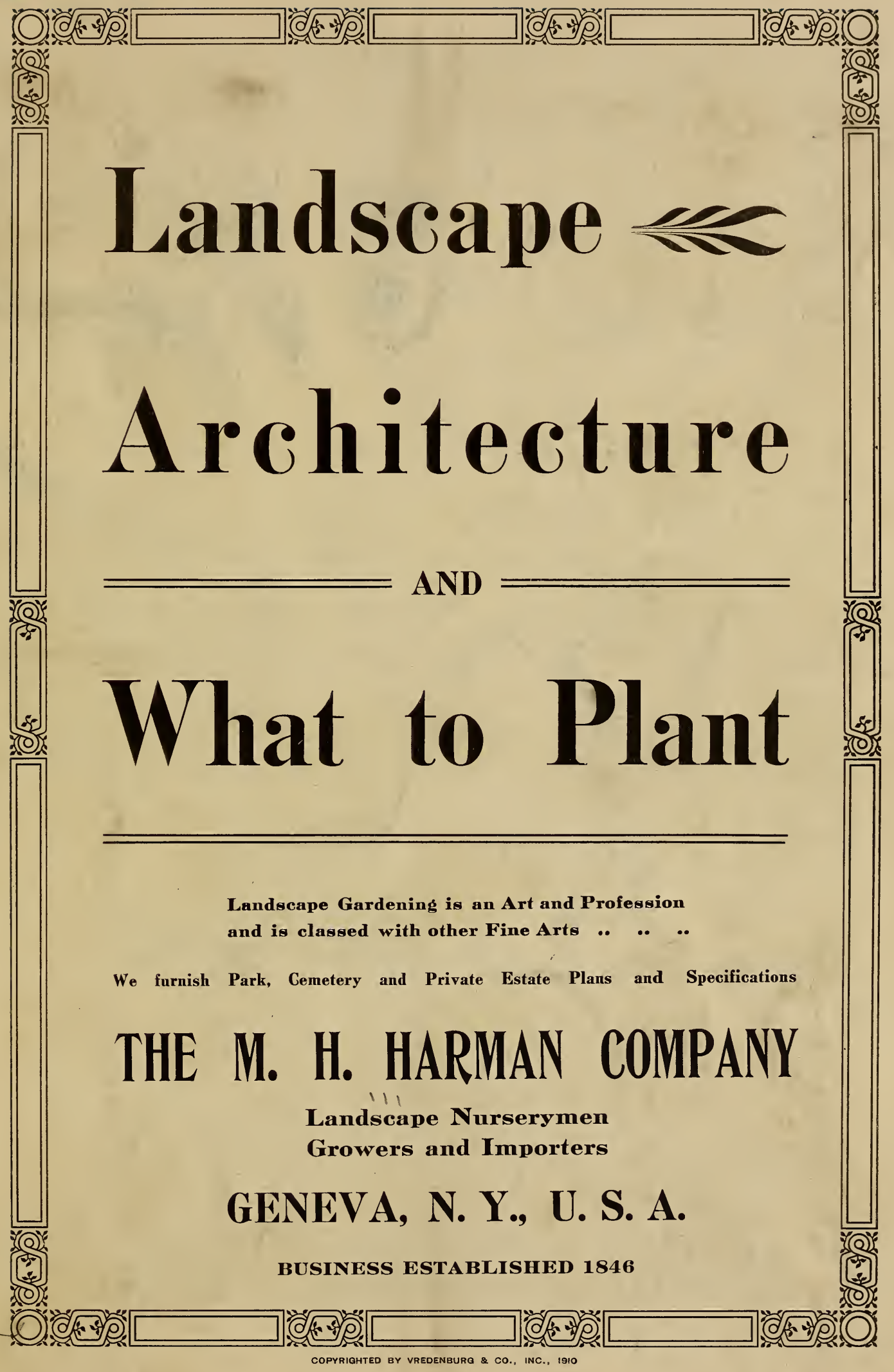




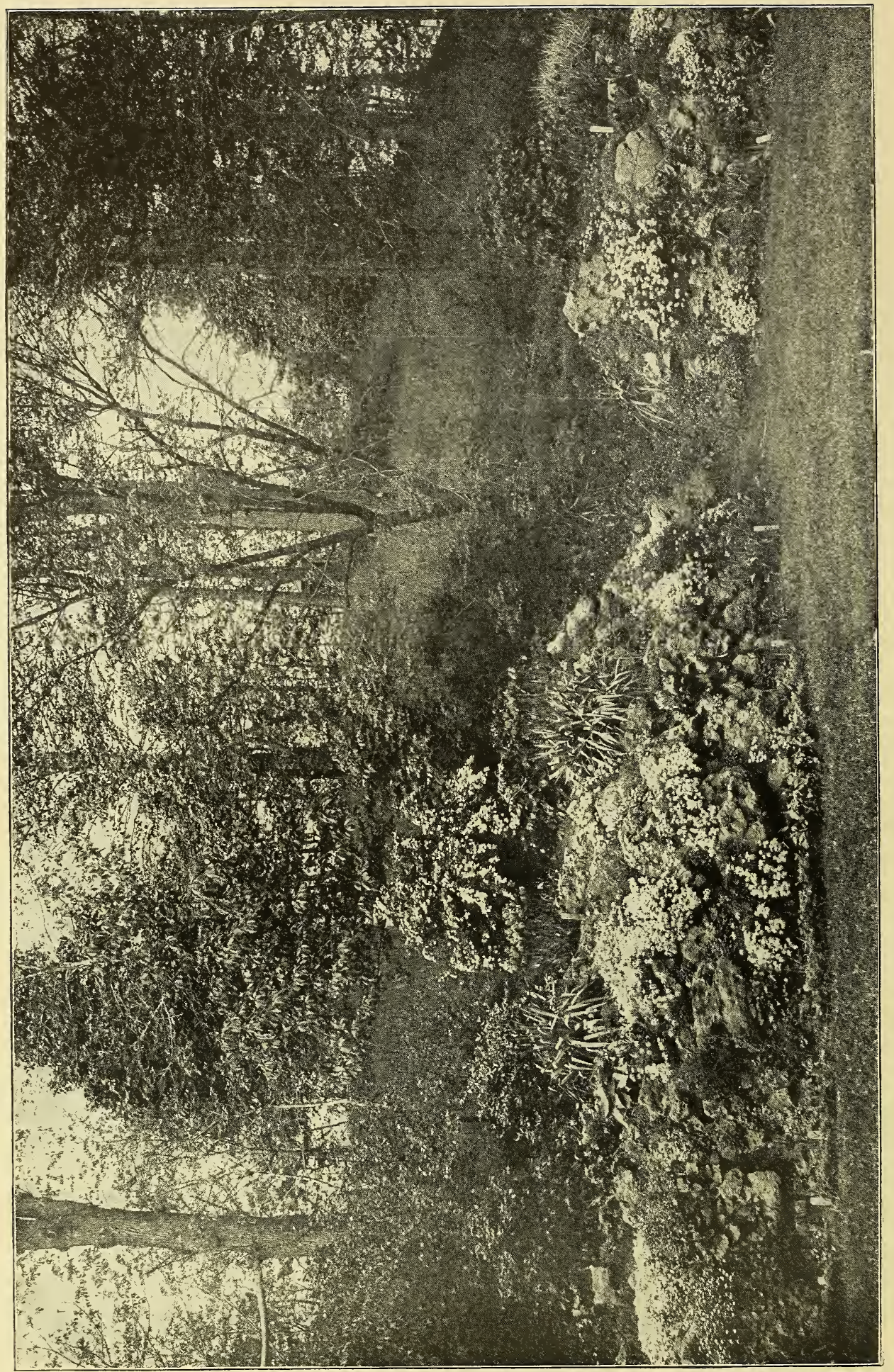

믈 

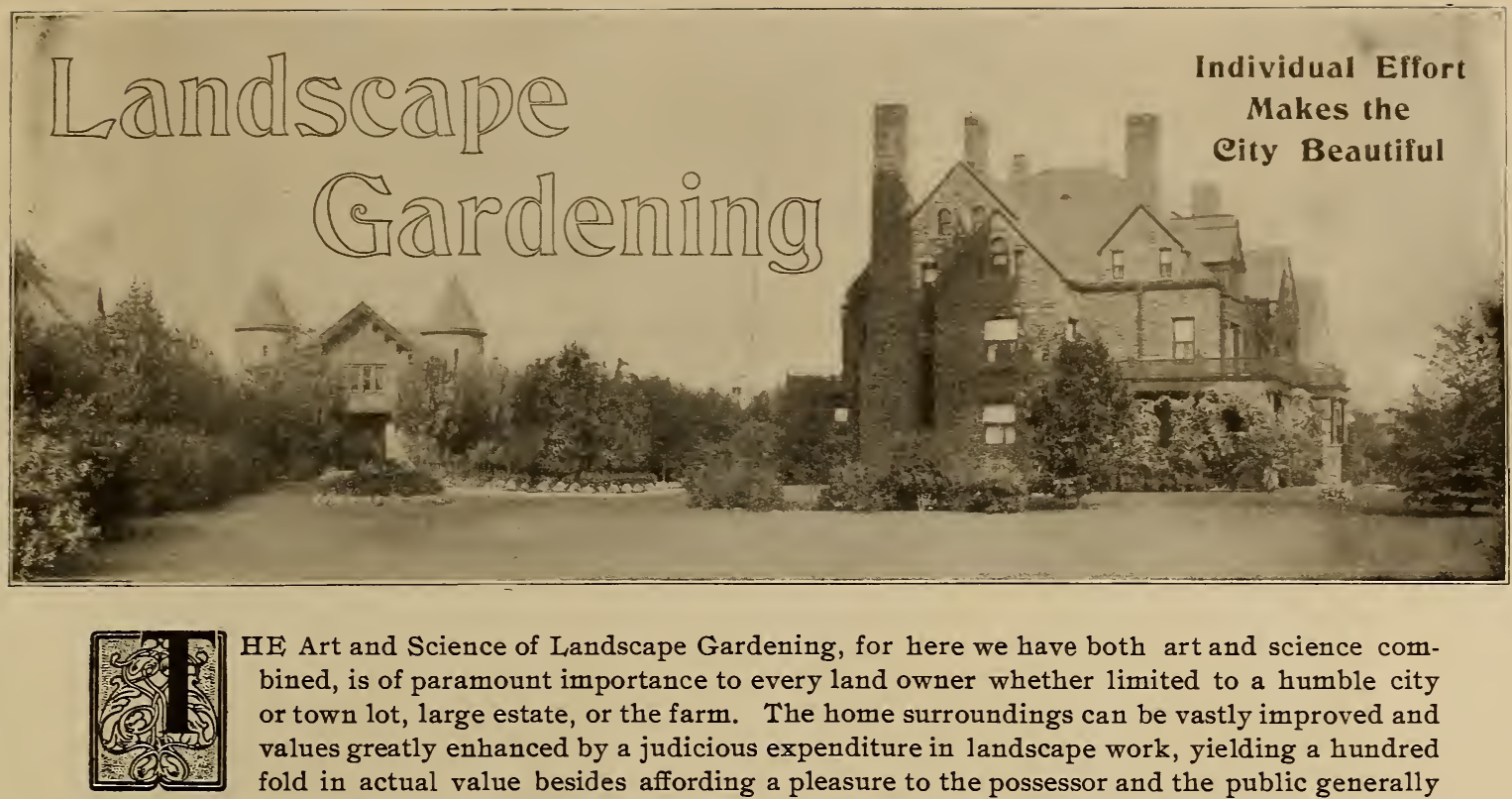

HE Art and Science of Landscape Gardening, for here we have both art and science combined, is of paramount importance to every land owner whether limited to a humble city or town lot, large estate, or the farm. The home surroundings can be vastly improved and values greatly enhanced by a judicious expenditure in landscape work, yielding a hundred fold in actual value besides affording a pleasure to the possessor and the public generally that can not be estimated in dollars and cents. Every beautifier of his grounds is a public benefactor.

The buildings may be ever so plain and even homely, yet with the grounds surrounding them nicely laid out and cared for, they are made charming; on the other hand a building ever so fine, if surrounded by illy designed and kept grounds, the effect is most unpleasant. It is manifest therefore, that if we would have a really beautiful home we must pay attention to its environment by a correct application of the means and material called for in the art of laying out grounds, and while this fact is so obvious yet how often do we see this important work entrusted to those without taste and having little, if any, experience in this very important work of landscape architecture.

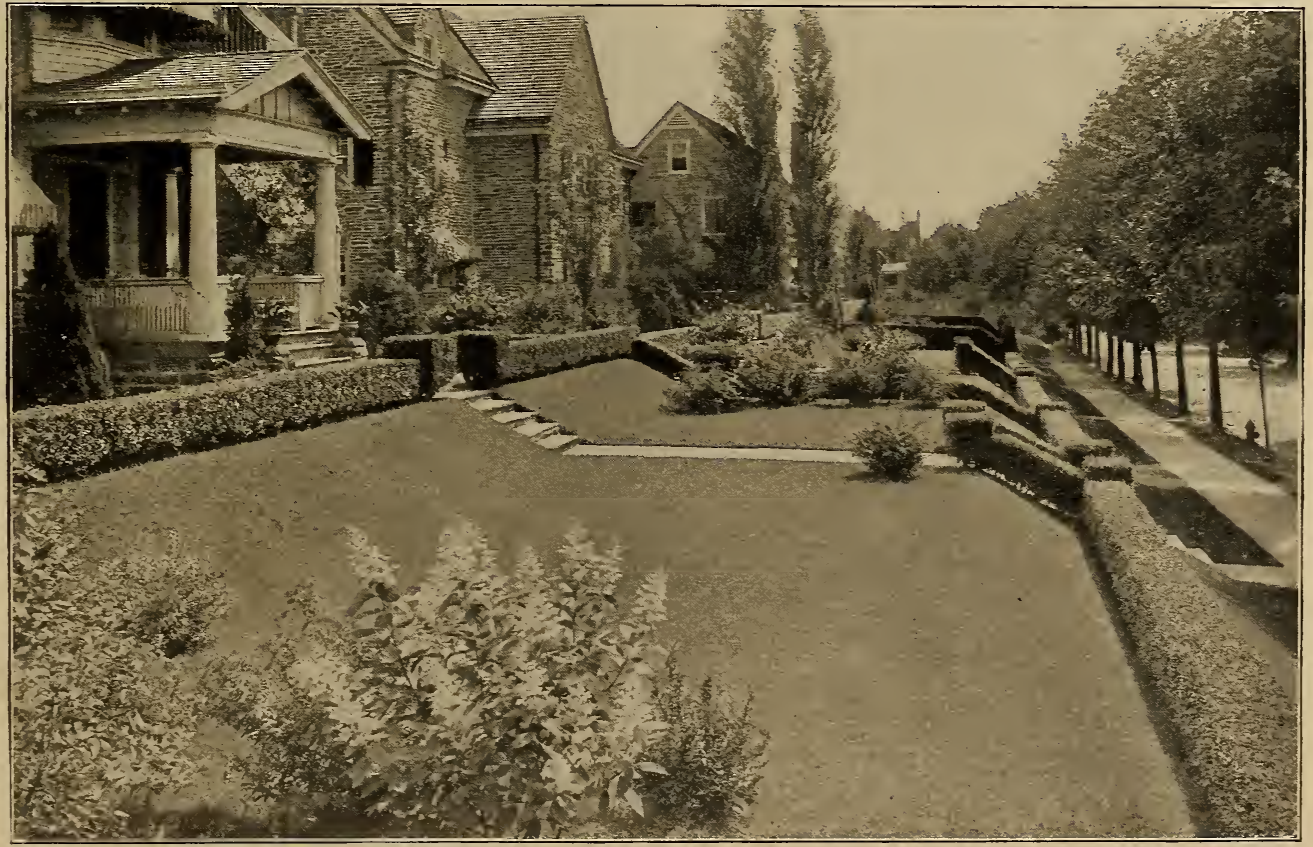

Join with your neighbors in pulling down the ugly fence; give place to the beautiful Privet, and add to the value of your property 


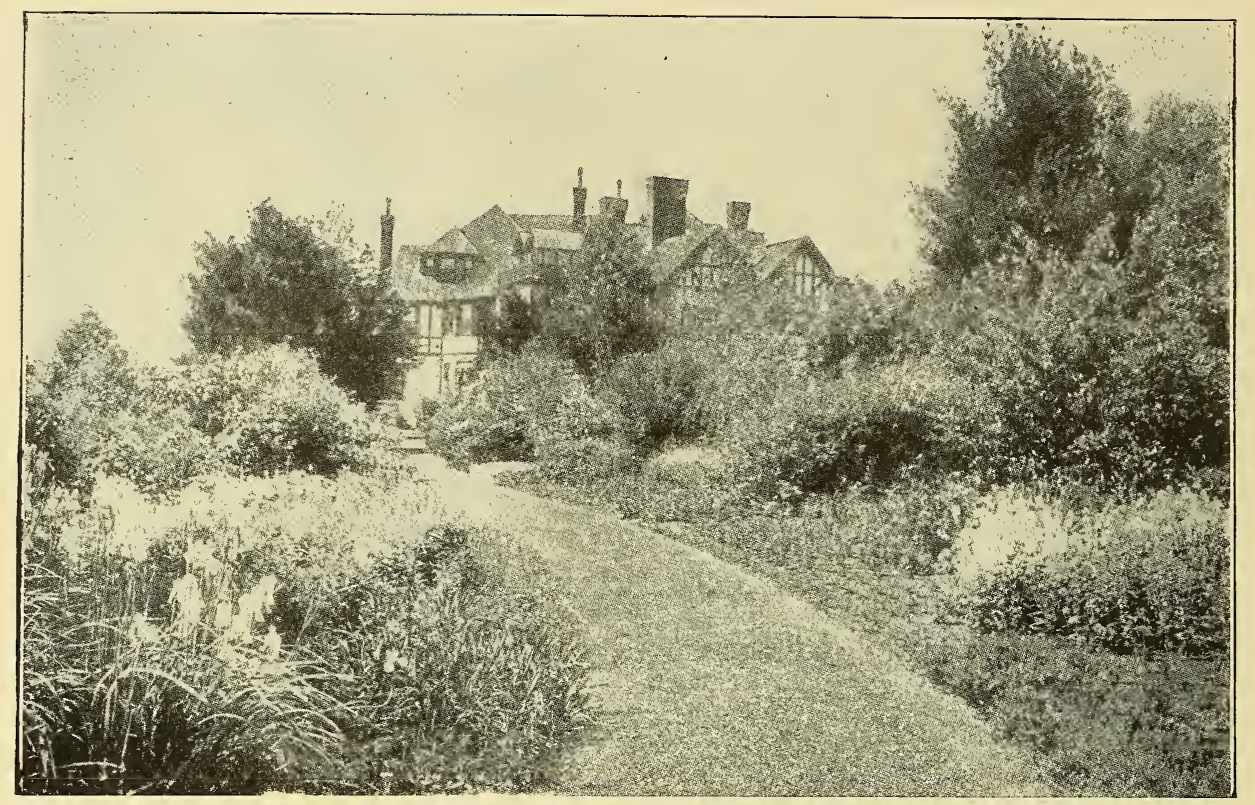

A drive bordered with a blending of Perennials and Shrubbery

It is not every one who is possessed of the necessary qualifications for this branch of work, for, to meet success, artistic taste must be combined with practical knowledge and experience. The ordinary gardener may plant and prune and cultivate, yet be ignorant of the art of combining, blending and getting the most out of what nature has provided.

In landscape work no hard and fast rules can be laid down, as every place presents conditions peculiar to itself, requiring special and independent treatment. As well attempt to lay down a set rule or design for the landscape painter, except it may be said that landscape designing is divided into two general classes. The old style or Formal, also called the Geometrical, and the new style or Natural.

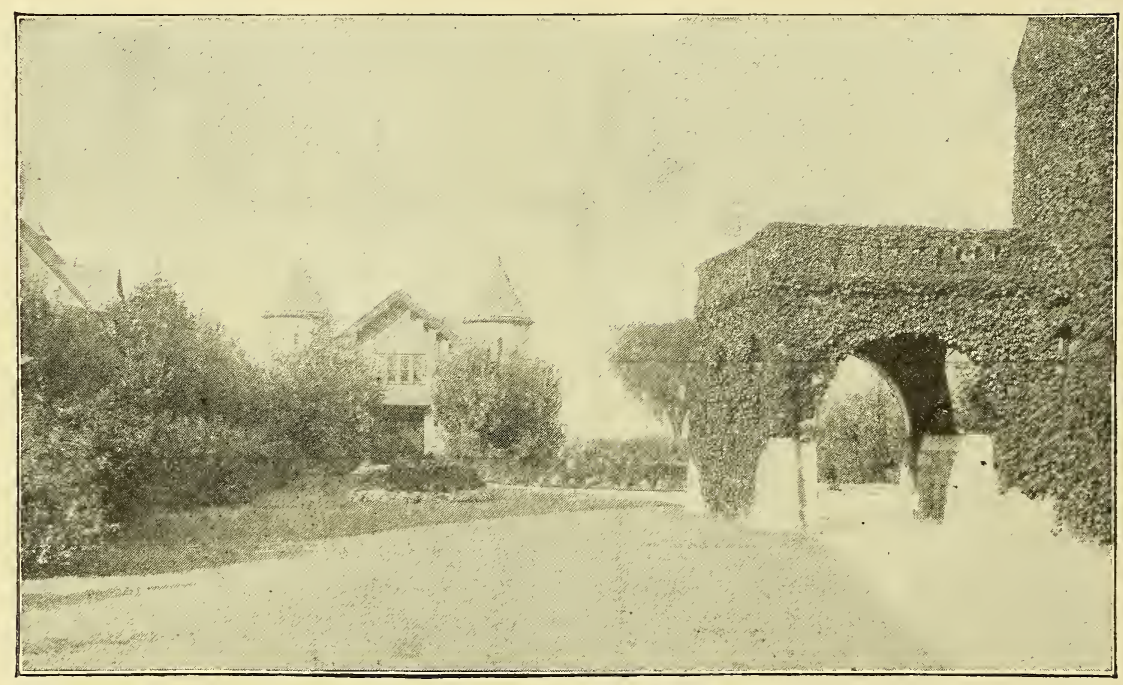

An attractive planting showing Shrubbery and Small Trees massed at the side, bed of Annuals in front of the Garage, Perennials and Shrubbery on the far side of the drive, with Ampelopsis Veitchil covering side of house and the porte cochere 


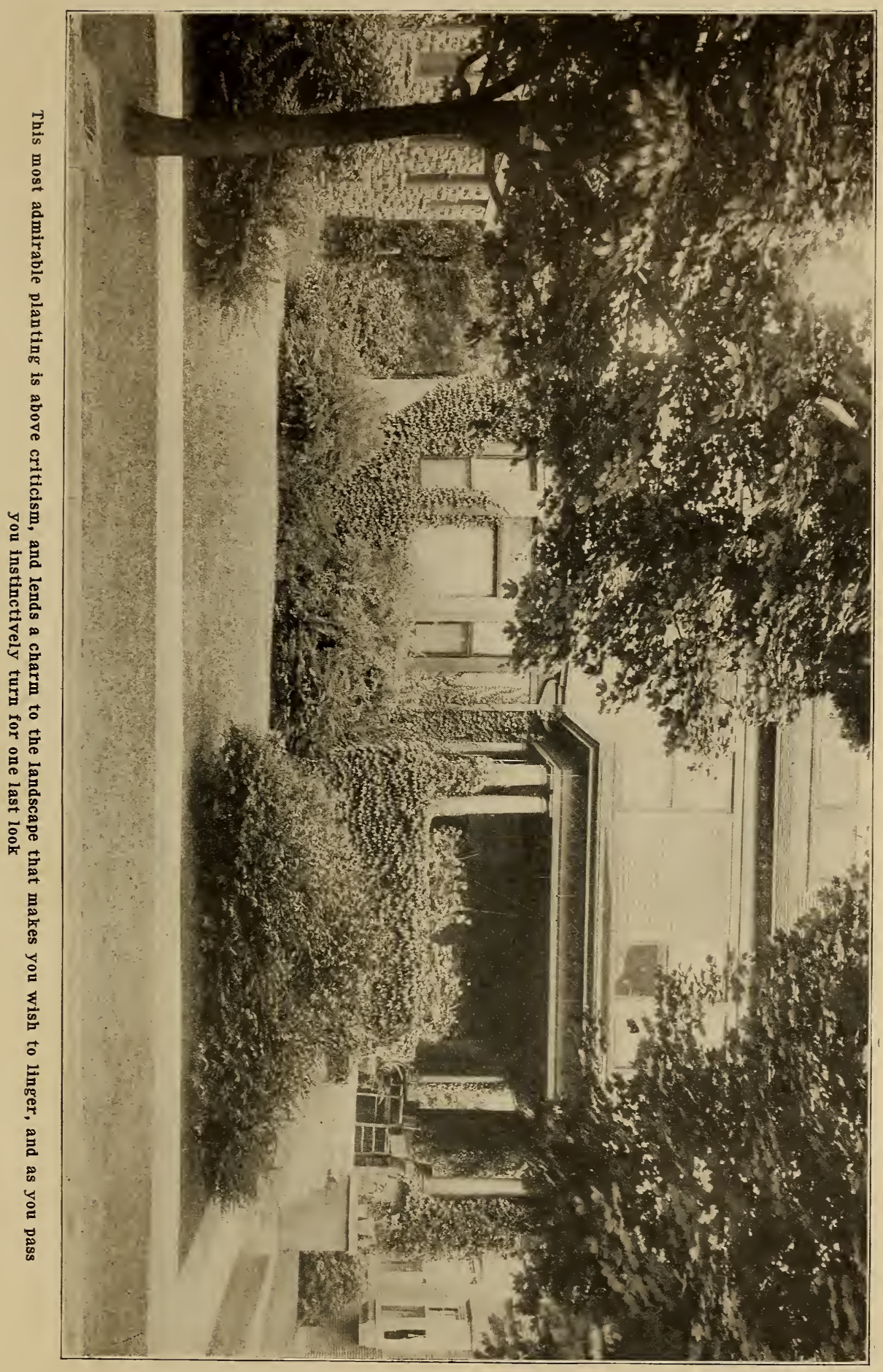






A modest arrangement for a town or city lot, showing a group of Thunberg Barberry in the foreground, a Cut-Leaved Weeping Birch, a kilmarnock Willow to the right, Annuals massed against the house, while at the south side were roses and vines

These ancient and modern styles have each their admirers, and each has its place in the scheme of beautifying, dependent on local conditions and what is best suited to the circumstances.

The modern style is essentially imitative, attempting to copy and reproduce the best in nature suited to the place, to correct its faults and cover its defects and enhance_its beauties, by selecting the most sightly objects and arranging them in the most pleasing manner.

The first object of the landscape architect is to study the surroundings in relation to buildings, elevations and other existing conditions. If there is scope for material changes, it may be necessary in order to obtain the best results to depress some elevations and accentuate others and, if possible to have

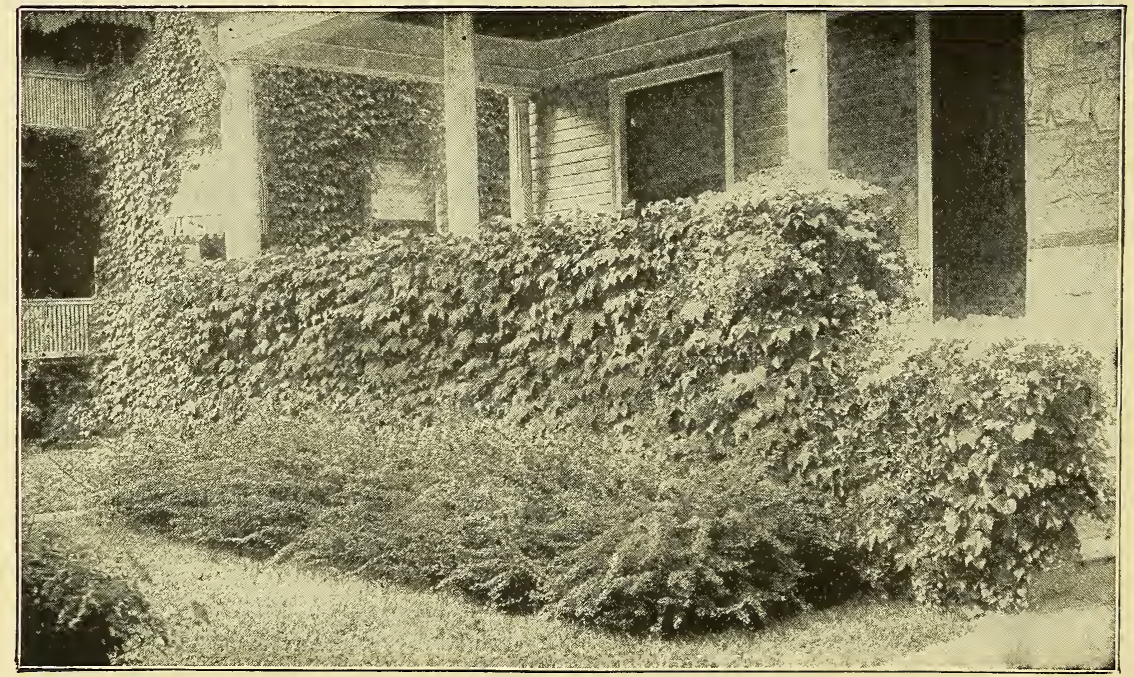

View showing a bed of Thunberg Barberry backed by a blending of Ampelopsis Veitchii and Paniculata Clematis 


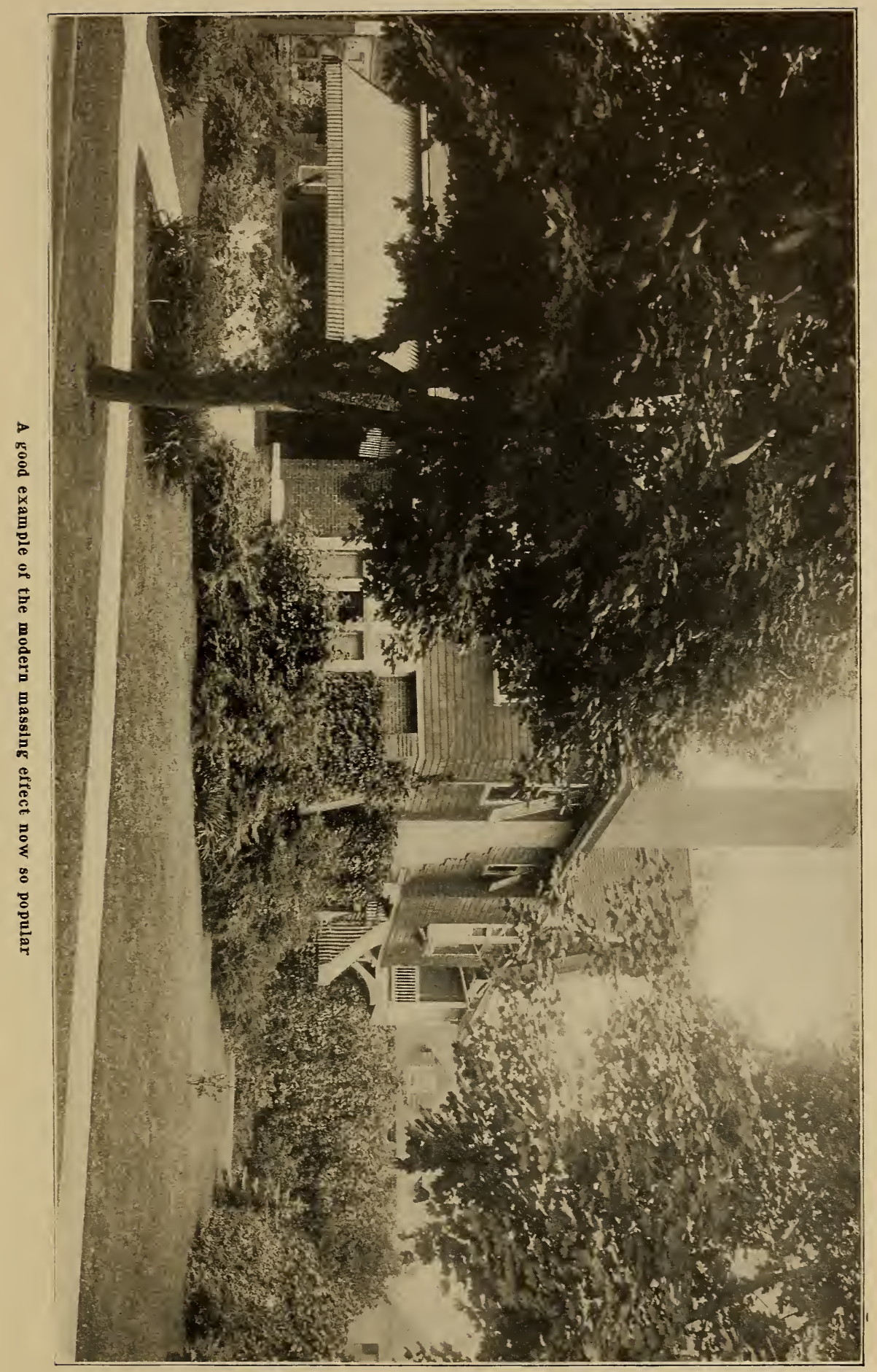




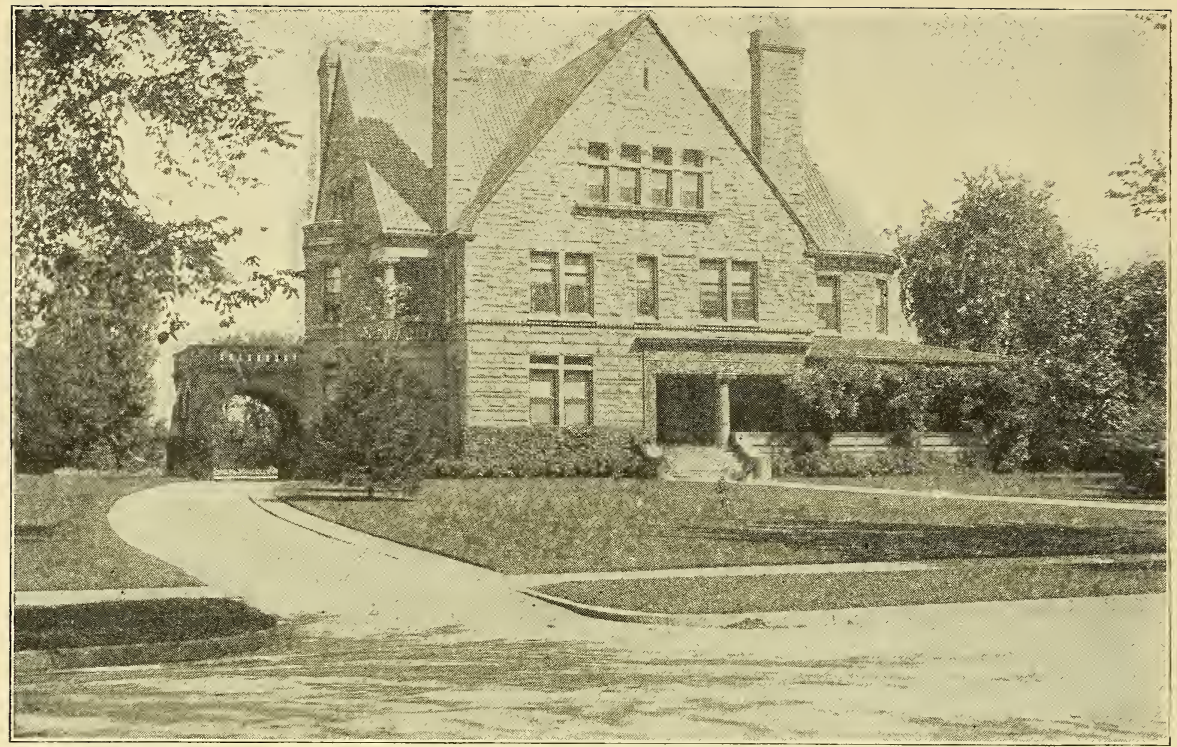

In this as in other views it will be observed that the front lawn is kept open and unobstructed

an artificial or natural lake at a reasonable cost, it is advisable to do so, as it always adds vastly to the beauty and interest of the landscape. Roads and walks are important adjuncts and should be laid out with regard to utility as well as beauty. By utility we mean they should always lead to some object or for some purpose and not run at random, as is too often the case, and should follow easy graceful curves without being too roundabont.

We now come to the most important feature of landscaping, the point requiring the greatest judgment and knowledge, and wherein most signal failures are made, either through want of experience or the fact that stock is purchased without reference to the requirements of the situation, that is, the proper selection of the nursery stock to be planted, for here the architect has to consider not the present but the future. He is not building for to-day only but for coming generations. The tree he plants to-day is growing in stateliness and beauty from year to year, becoming more and more "a thing of beauty and a joy forever."

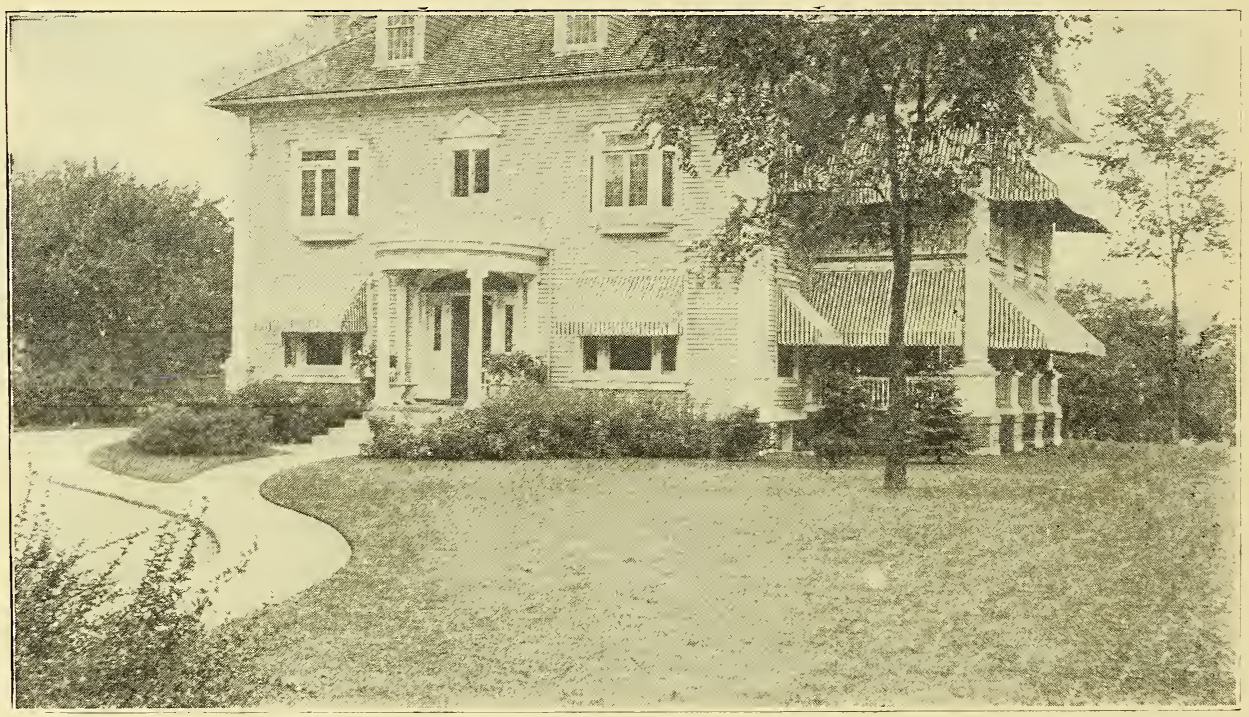

Still another view of open effect in Modern Landscaping 


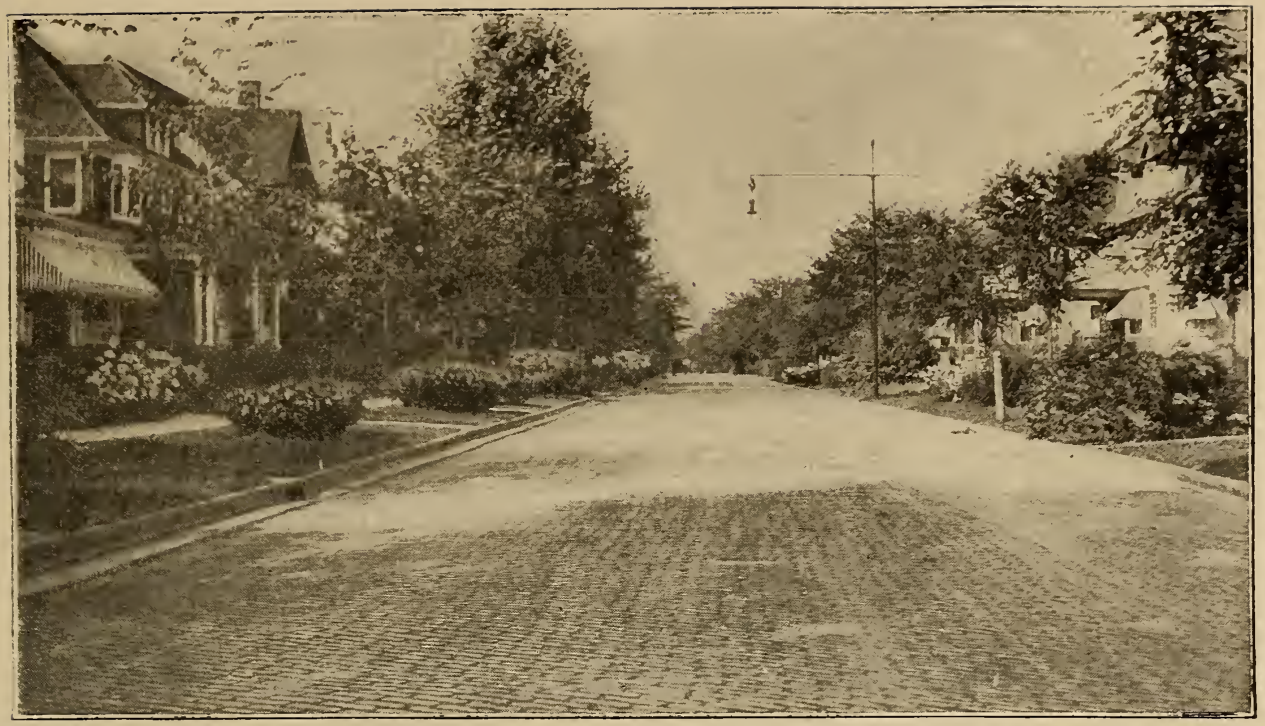

Street scene showing effect of planting shrubbery between walk and curb

The most important element in producing a pleasing landscape is a proper blending of trees, shrubs, vines and plants, and here the greatest care has to be exercised both in the selection and the placing, as this is the finishing touch of the artist and makes or mars it as a finished picture.

The house being the main feature, all planting must be done with reference to its character and position, care being exercised not to obstruct sightly views, unsightly objects must be screened, and principal masses showing irregular outlines so placed as to stretch along rising ground if possible, and so arranged that they will harmonize with the surrounding property.

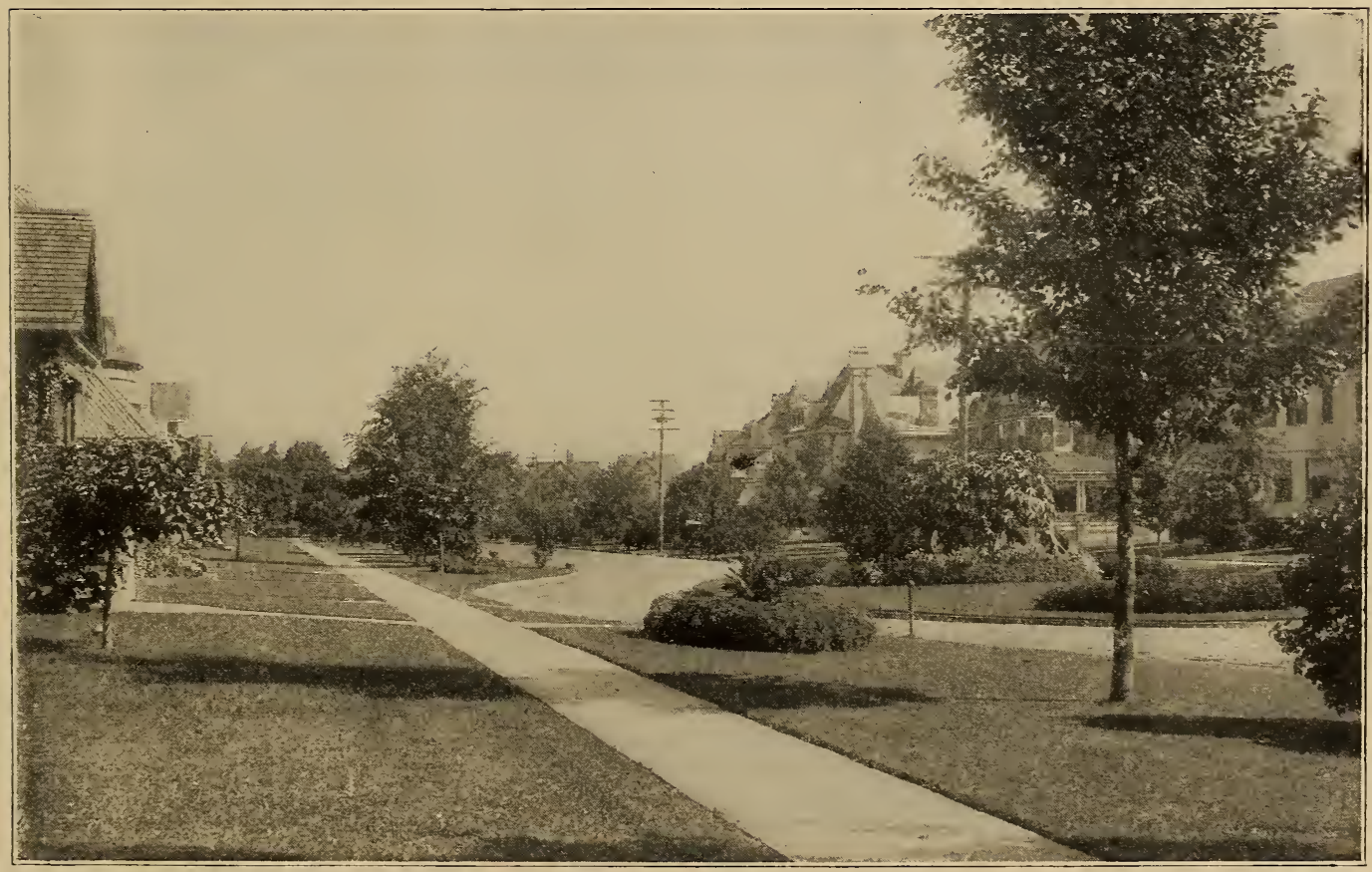

Here we have the pleasing park effect in street designing, calculated to give a degree of class and privacy attainable in no other way 


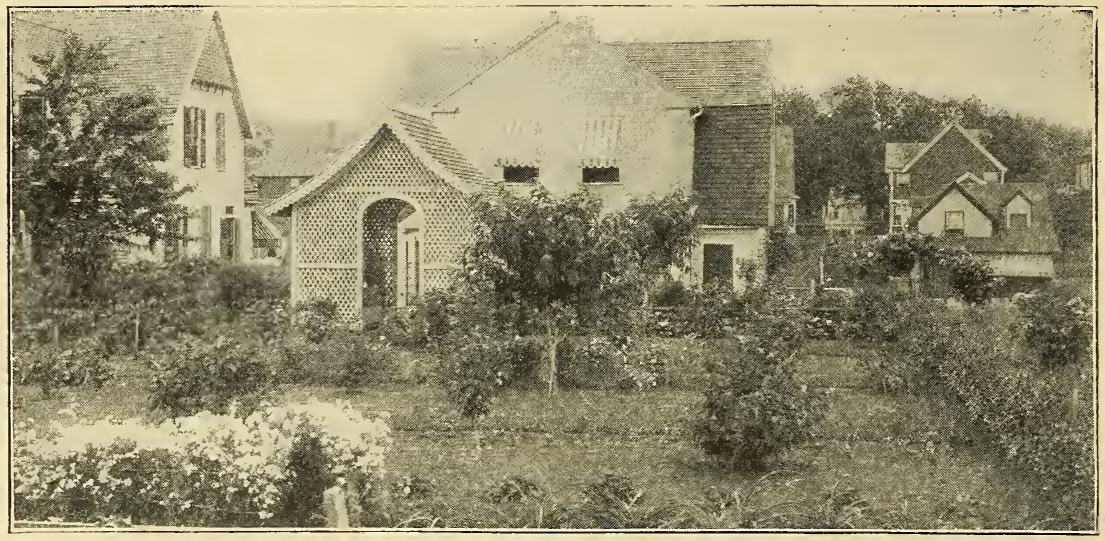

The most humble home, however homely, can be made attractive and loveable by a small expenditure of time and money, and the back yard should receive the same consideration as the front,

in order to have a harmonious whole

The best effect of water in the landscape depends on trees and shrubbery as an accompaniment, with its reflected forms, shady recesses and scintillating lights and shadows.

Plantings should be generally in groups and masses, with here and there individual specimens, but with plenty of open lawn for light, air and view.

Projectors of suburban homes would do well to consult the landscape engineer before the erection of buildings, as their location has much to do with the effectiveness of the future embellishment of their surroundings, and much would be gained in every way, for then exposures, soils, drainage, walks, roads, etc., could be taken into consideration, giving results not otherwise possible to obtain and generally at much less expense.

As a large part of the joys of life are afforded through the eye, the more of beauty and grandeur it takes in the more is the observer refined and ennobled, and the beautiful scenes passed in our daily walks are not unfruitful; hence to our neighbor and ourselves it becomes a duty to beautify wherever and whenever possible and no duty affords greater pleasure in its fulfilling.

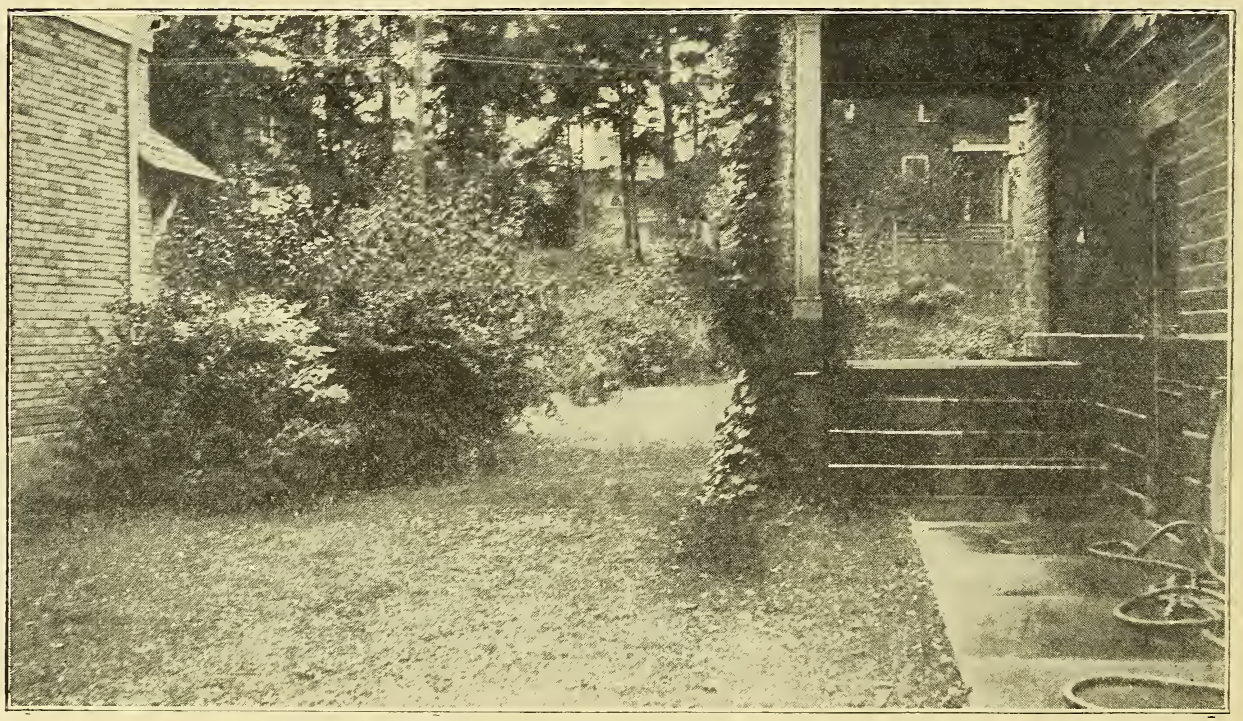

Side yard showing shrubbery, etc., between buildings, reaching back to mass plantings in the rear 


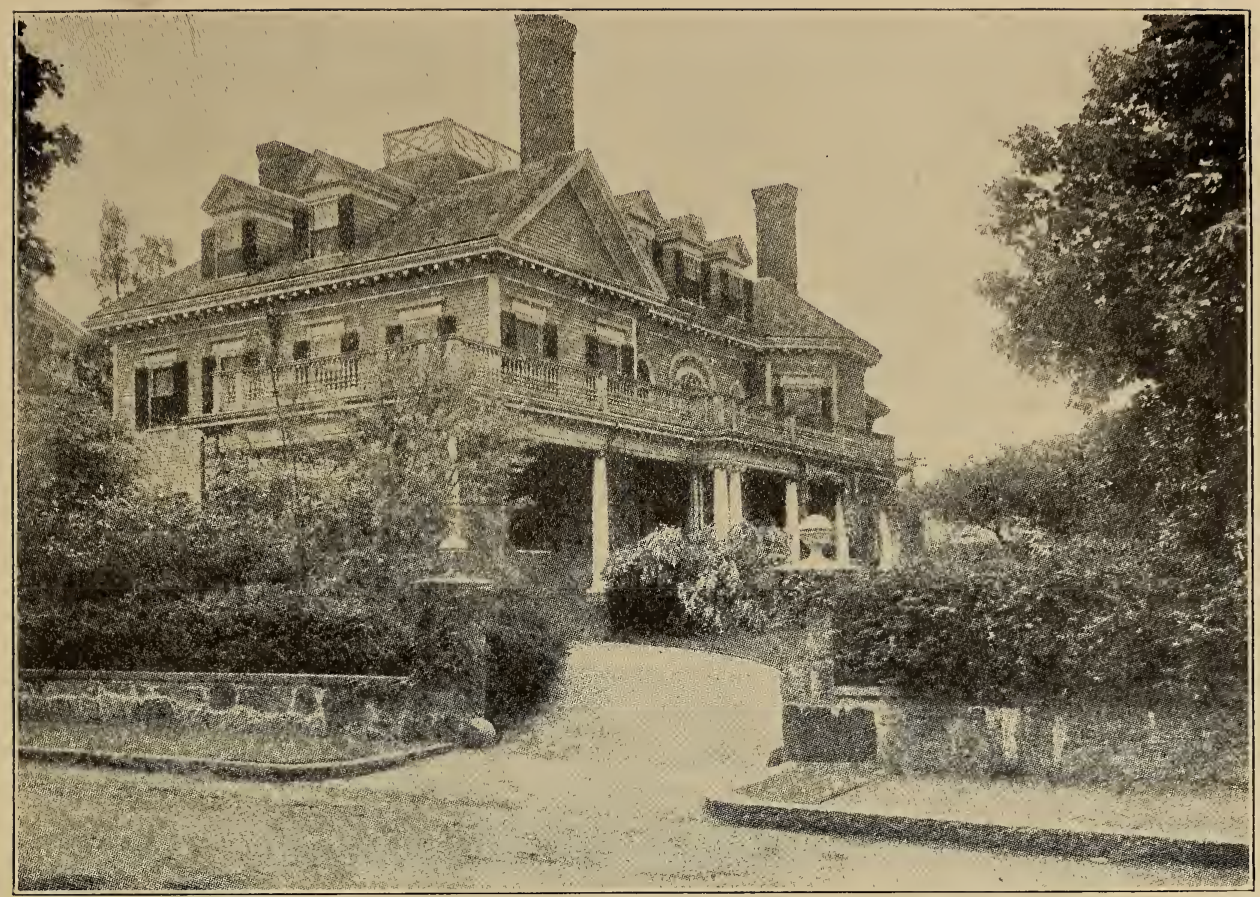

A profuse but none the less pleasing and effective planting that appeals to the beholder not at first sight only but of which one never grows weary

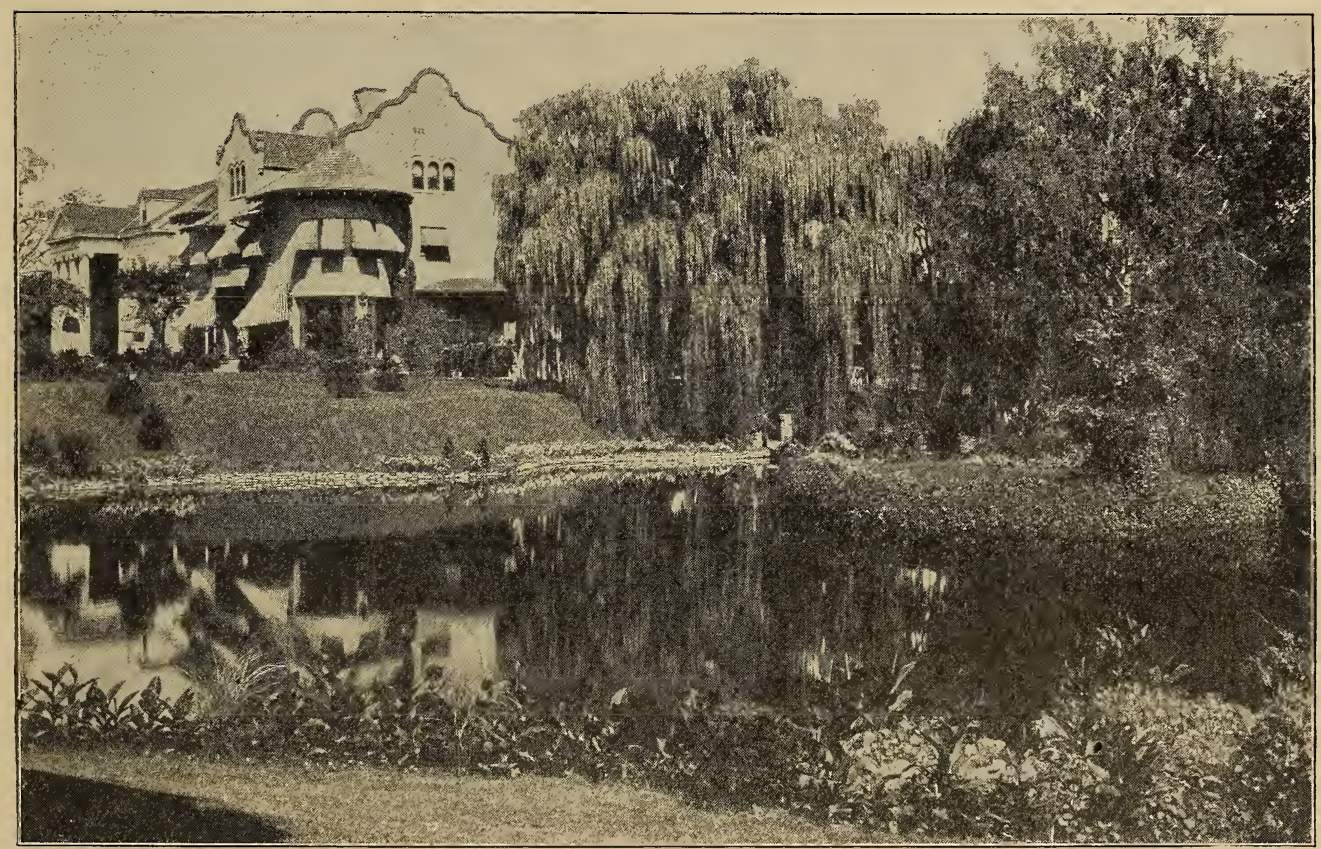

The charming beauty and restful soothing effects of water in a landscape are so generally known and appreciated that it is hardly necessary to remind you not to neglect taking advantage of any stream, brook or spring that will render such an adjunct to happiness possible 


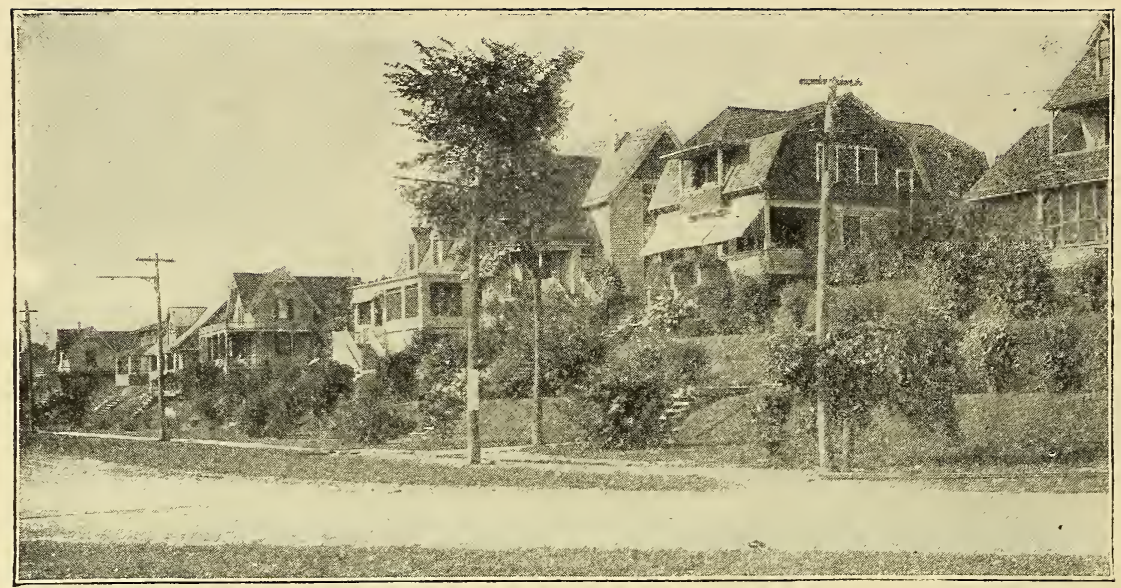

Here we have the effect of terracing and planting a steep side hill

It is a peculiar fact that architects, almost without exception, ignore landscape effects, which do so much to enhance the beauty of their work, and rarely take this feature into consideration in locating buildings; but we believe the time is not distant when they will recognize its value and will first seek the advice of the landscape architect, before determining these matters.

Where possible the main building should be located near the northern boundary of the plot, giving all principal rooms a southern and eastern exposure, with massed plantings on the northern and western boundaries, thus affording protection from the prevailing northwest wintry winds and shielding more sensitive and choicer plants and trees that grace the lawn.

Driveway, also used as a walk from the street or road, should approach the house and stable or garage beyond, with a graceful curve, from which may branch narrow walks among the shrubbery, etc., to the several points of interest, affording opportunity for plantings in the way of borders of perennials and annuals aceording to the individual taste.

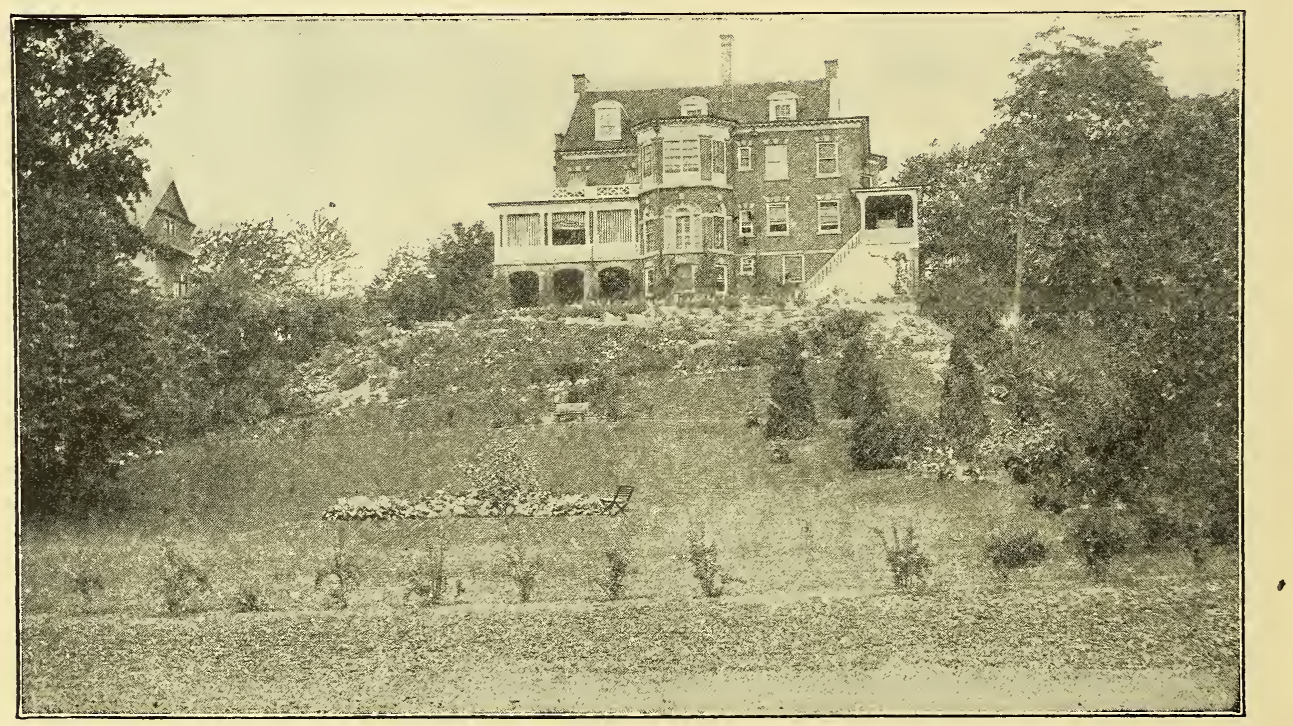

We here have another rear view showing the effect of terraces sloping right and left alternately, thus making an easy grade and prolonging the ramble 


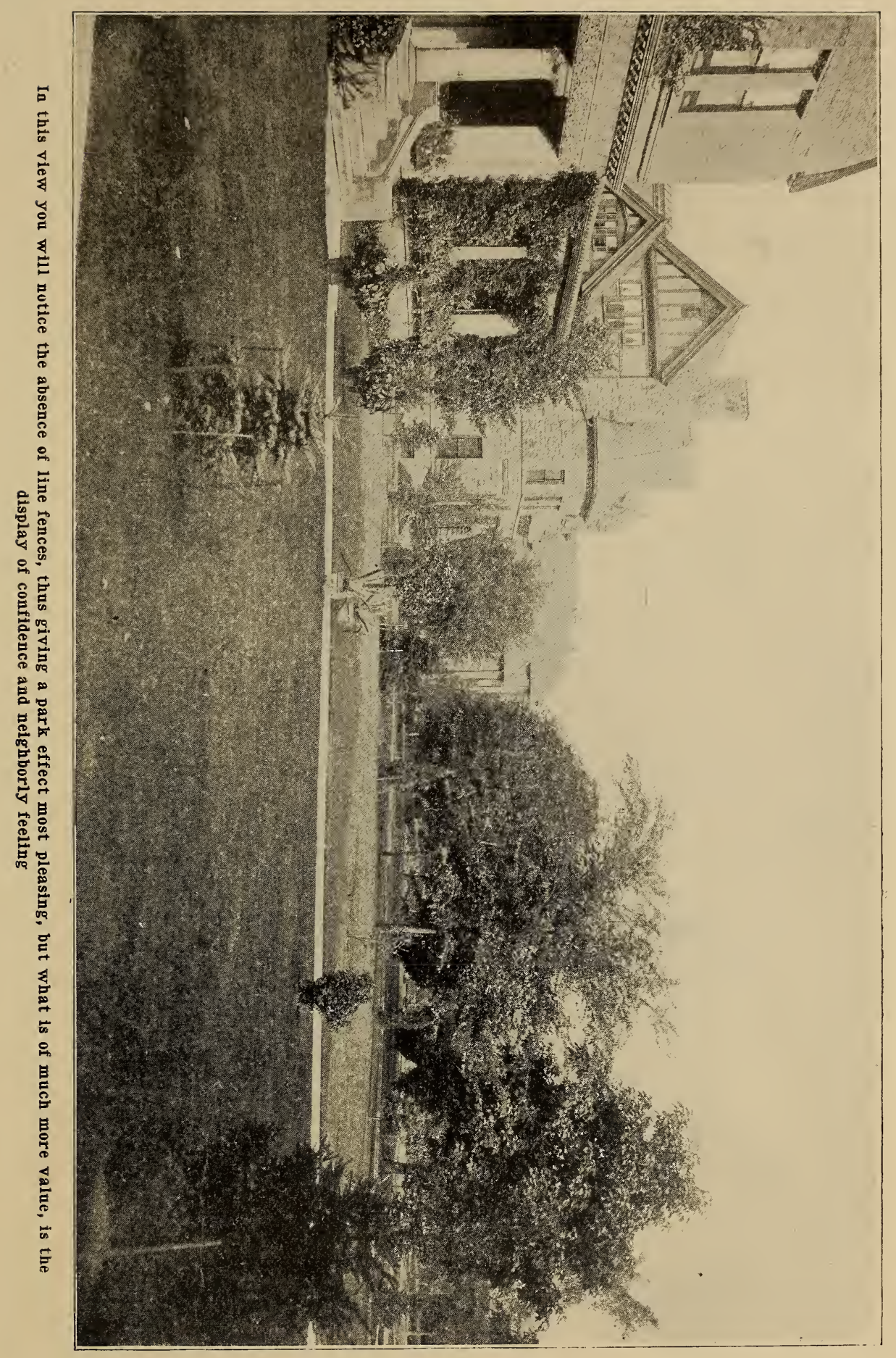




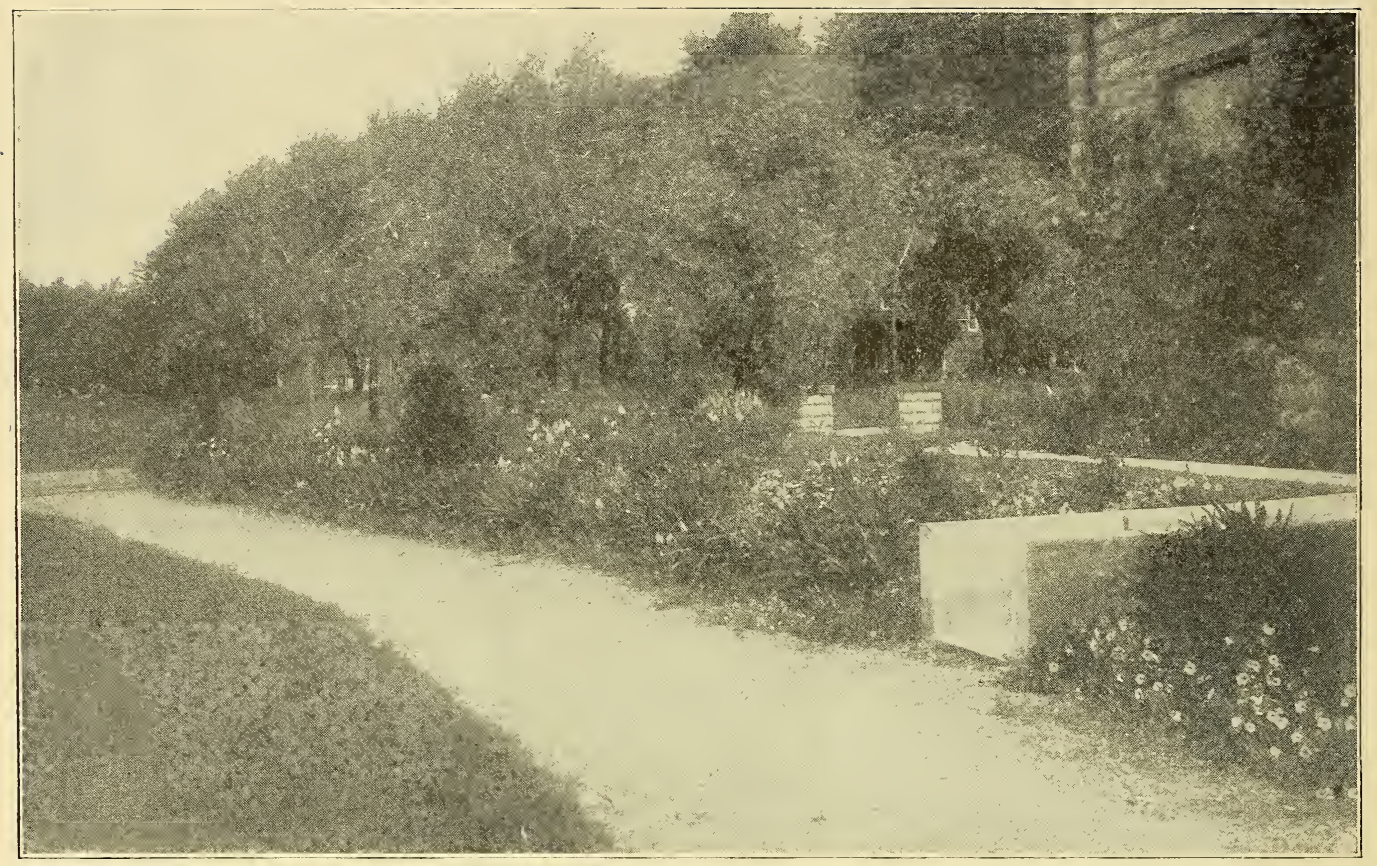

A private drive bordered with perennialsand annuals, with shrubbery, trees and vines in the background, quite devoid of system, but very effective

For divisions between properties or separation from the highway there is nothing more economical and beautiful than a well kept hedge, which nature keeps freshly painted from year to year without cost and is not subject to decay. For this purpose there are many beautiful and useful plants, but all things considered, California Privet (Ligustrum ovalifolium) is probably the best, as it is almost evergreen, retaining its shiny green foliage late in the winter, bears shearing well, may be trimmed to any form or size and is a rapid grower, forming a good close hedge in a short time, and where this is not found sufficiently hardy one of the more hardy varieties of this family may be substituted and will be found almost equally desirable. A close second to the Privet is the Thunberg Barberry (Berberis Thunbergii), a dense, low growing shrub forming an impenetrable hedge, being armed with sharp spines and bearing a profusion of brilliant red berries which remain all winter. This is preferred by many for the reason that it requires little or no trimming and also for the beauty of its autumnal foliage, which is most brilliant. There are many other useful and beautiful plants suitable for hedging, giving a wide range for individual tastes.

Where there is plenty of room, some of the evergreens are both useful and beautiful, giving protection from the winter winds and break the monotony of the winter landscape.

Where it is possible to do so it is sometimes most effective to completely screen the interior from the highway, arranging it so that a sudden turn in the drive brings it into view with all its beauty. We have in mind places of this kind where strangers coming upon it for the first time will stop in openmouthed astonishment and give expression in such terms as " $\mathrm{Oh}$, isn't this beautiful!" "What a lovely place!" etc., all of which makes the owner feel well repaid for the care and comparatively light expense expended upon it. 


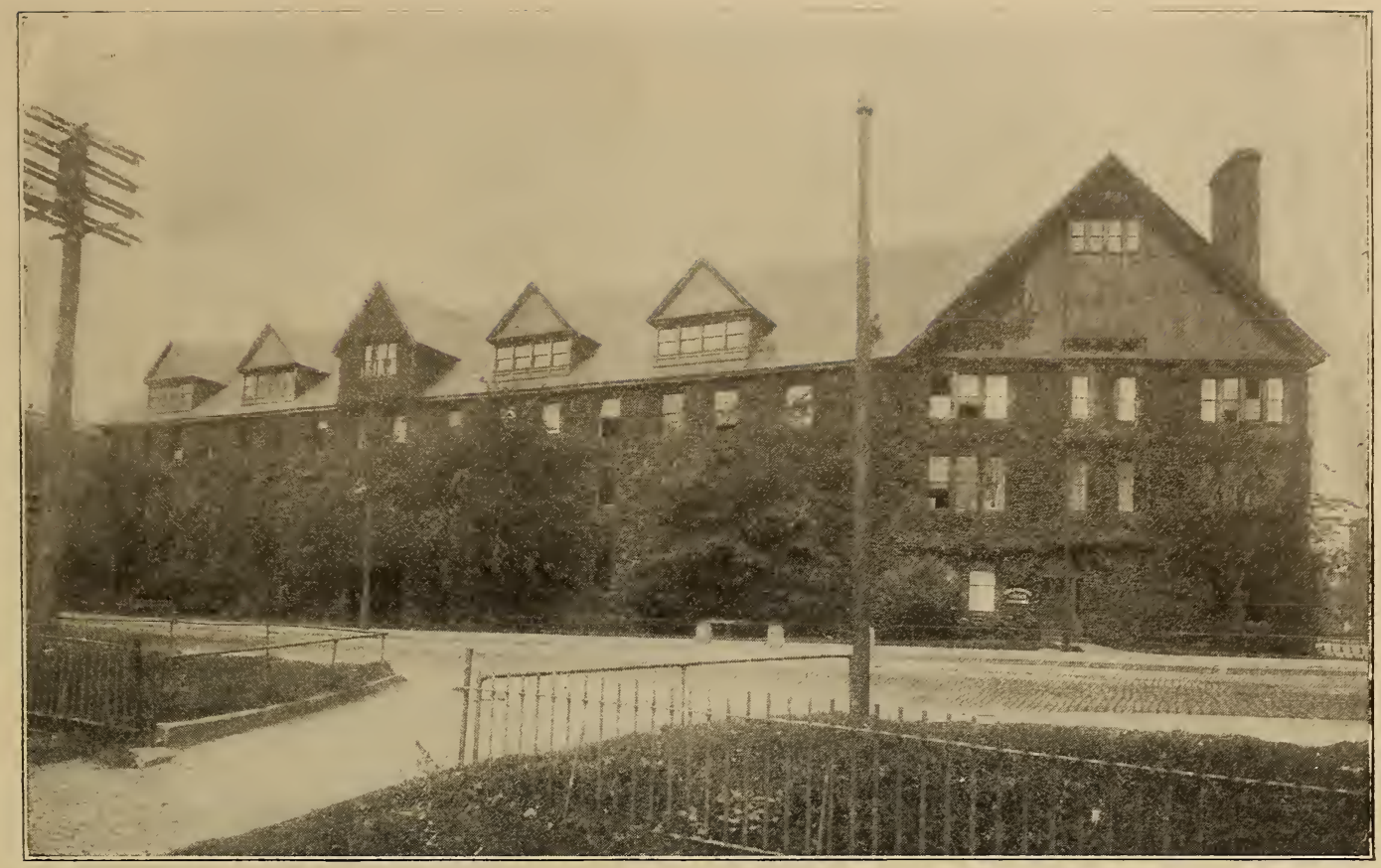

Here we see how our factory buildings may be made pleasant and inviting, and calculated to attract the better class of help. Our manufacturers are just awakening to its importance and the future will see it much more extensively practiced. Ampelopsis Veitchil is the vine here used

Where space is limited, as in the case of an ordinary city or village lot, say $50 \times 120$ feet, the problem of beautifying that confronts the ambitious owner is one requiring careful consideration and judicious handling, especially where co-operation of neighbors is not possible with a view to a harmonious whole, as surroundings must be taken into consideration, and these are often such as to tax the ingenuity of the most skilled designer; and yet landscape gardening should be used, and is quite as valuable, in connection with the humble home as with the laying out of grounds of a park or vast estate, and its moral and elevating influence is even more pronounced and valuable for the reason that it comes more in touch with the masses, and its influence is contagious. Let one lot owner "fix up" and immediately his neighbors begin to "spruce up" also, unless, perchance, he be so unfortunate as to have utterly lost all sense of pride and ambition. Thus the move on the part of one to improve the exterior of his home, however humble, will often improve the tone of the neighborhood, with a corresponding improvement in its sanitary condition. And let it be borne in mind that no improvement is complete unless it takes in the back yard as well as the front, for this is quite as important and will afford quite as much satisfaction and pleasure, and what is more, may be made profitable, for here beauty may be combined with the practical, and the ground made to produce both luscious fruit and fragrant flower in company of the succulent vegetable, besides affording healthful and pleasurable exercise in caring for them, and no home is truly perfect without all these things.

Such a home will probably average $\$ 3,500$ ( $\$ 1,000$ for lot and $\$ 2,500$ for building). One hundred dollars expended for stock and planting is less than 3 per cent. of the above amount, and if judiciously expended, will in two years' time increase the value from 10 to 25 per cent. and increase each year thereafter as trees and shrubbery increase in size and beauty. No other investment yields so great a return in value and satisfaction.

The diagram on next page shows a very good corner lot arrangement for a city or village plot, the space between the fruit trees and the line hedge at the back being devoted to small fruits or vegetables. 


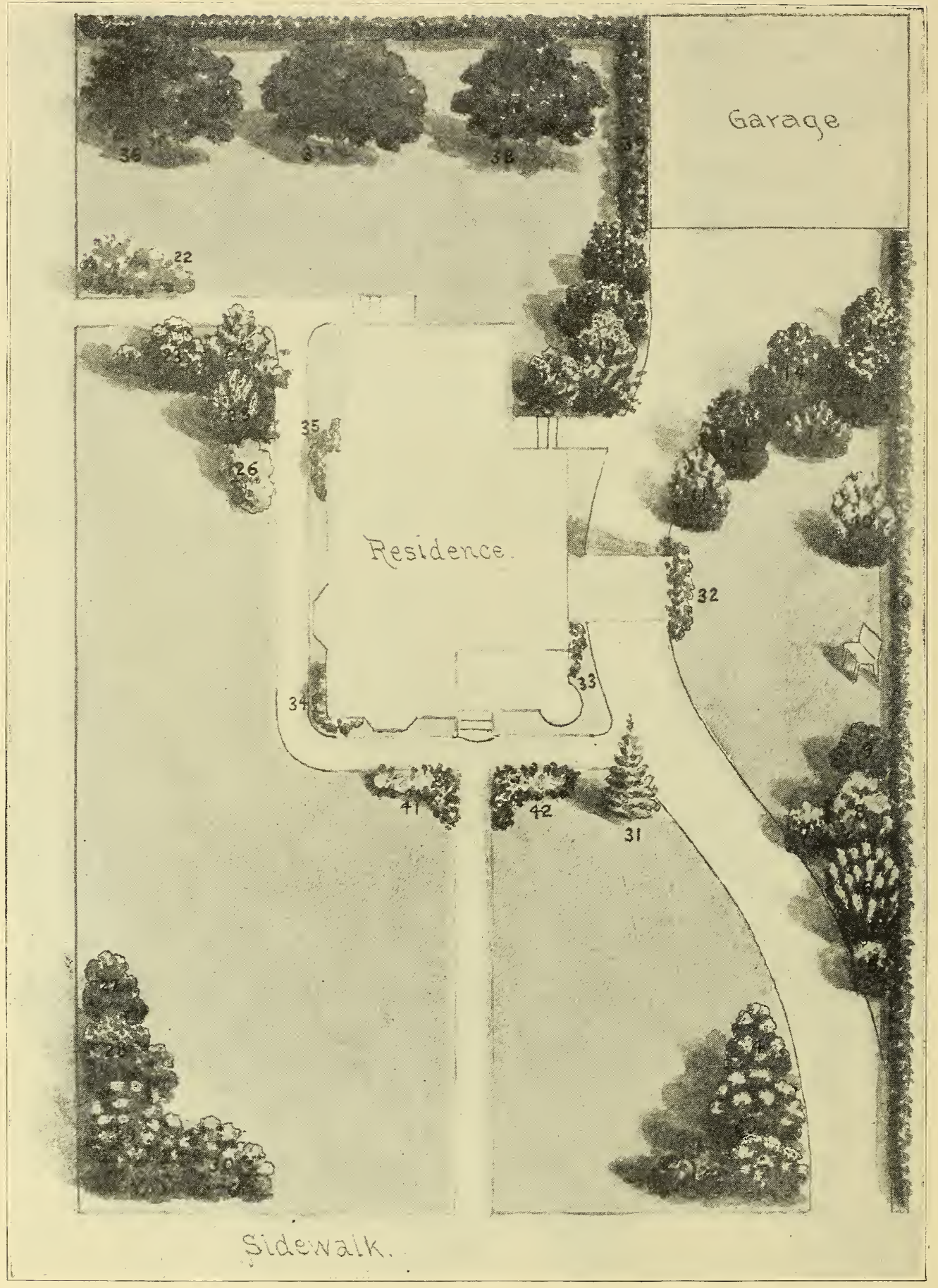



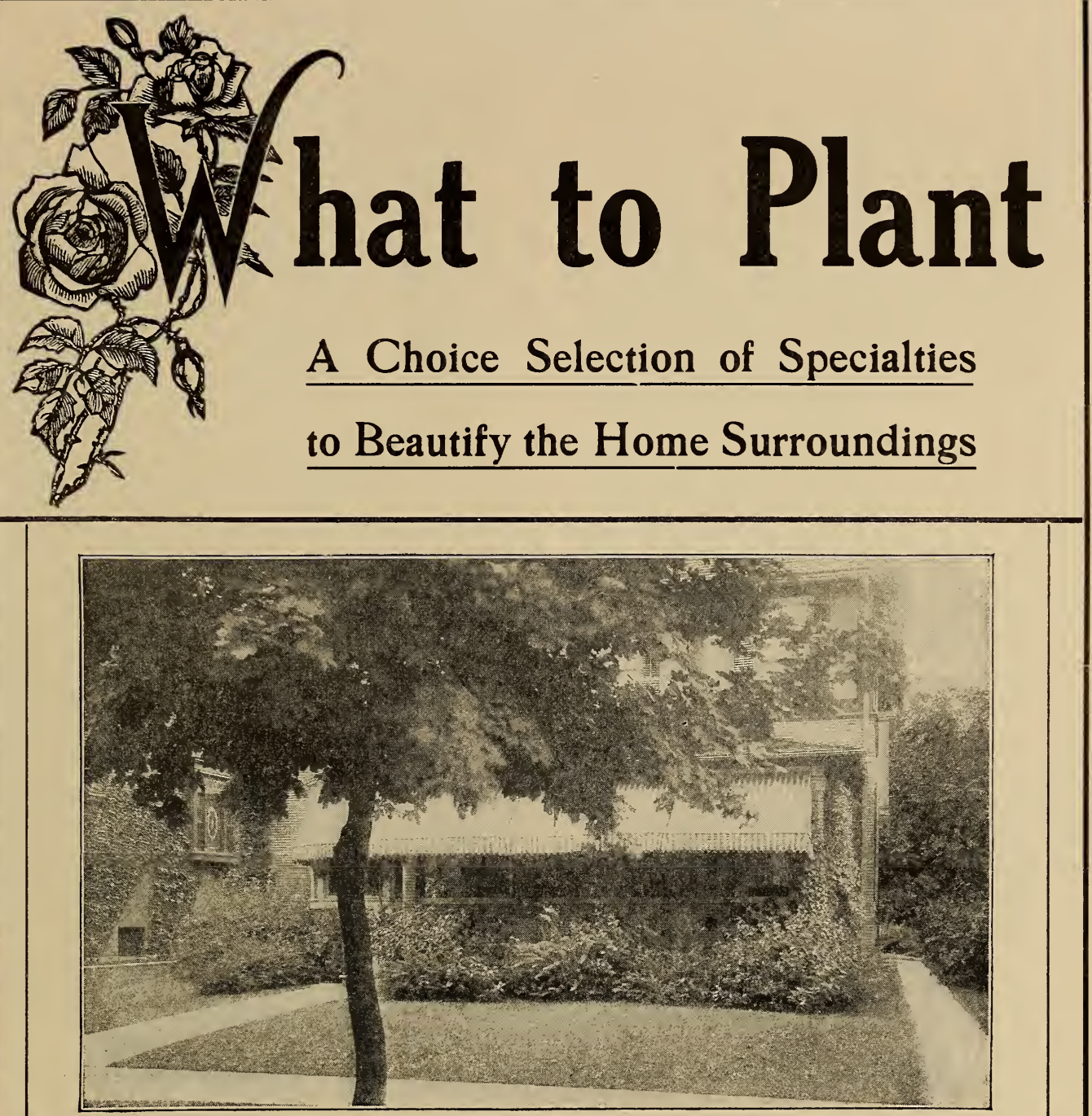

A neat arrangement for a small front lawn. View unobstructed

व In the following pages will be found a carefully selected list of hardy trees and shrubs that will thrive under ordinary conditions and give satisfaction, having been thoroughly tested over a wide range of country. In the extreme North or South it might be necessary to substitute in some instances.

G In the limited space and scope of this booklet it is not possible to give plantings suitable for every part of our vast country with its varying conditions and climate, and the planter should carefully study local conditions and select those varieties best suited to them, and if not competent to do so, submit the matter to some one who is, otherwise disappointment and loss will most surely follow. 


\section{* * TREES}

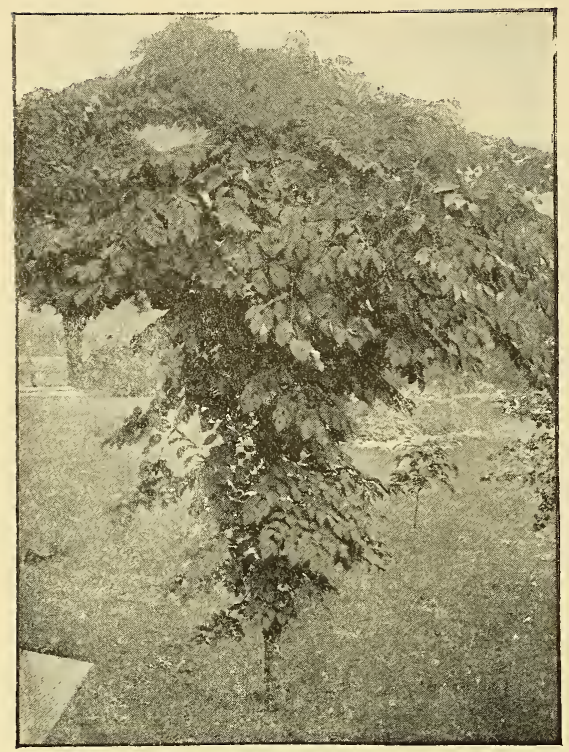

Aralla Spinosa.

\section{Ailanthus-Tree of Heaven.}

From Japan. A lofty, rapid growing tree, with long, elegant, feathery foliage, exempt from disease and insects. One of the most distinct of ornamental trees, with pinnate foliage. Useful to produce tropical effects.

\section{Angelica Tree, or Hercules Club.} [Aralia Spinosa.]

A singular looking, small sized tree with very prickly stems, pinnate leaves, and bearing immense panicles of white flowers in midsummer. Very useful to give a tropical effect to gardens and for odd looking clumps for background.

\section{Bechtel's Double Flowering Crab.}

A medium sized, hardy ornamental tree of great beauty. When in bloom this tree presents the appearance of being covered with roses. Flowers large, fragrant and beautiful.

\section{Plane.}

A favorite avenue tree in Europe, and becoming very popular in this country for the same purpose. So far it has escaped the attacks of insects in our cities. It is a rapid, clean grower, forming a large, spreading tree, attaining a height of 40 to 50 feet, and cannot be too highly recommended where a large growing tree is wanted. Thrives in either high or low ground.

\section{Horse Chestnut.}

A very beautiful, well-known tree, forming a round, compact head, with dark green foliage and an abundance of showy flowers early in Spring. Very desirable on account of its hardy, healthy habit. When fully grown, 40 to 50 feet high.

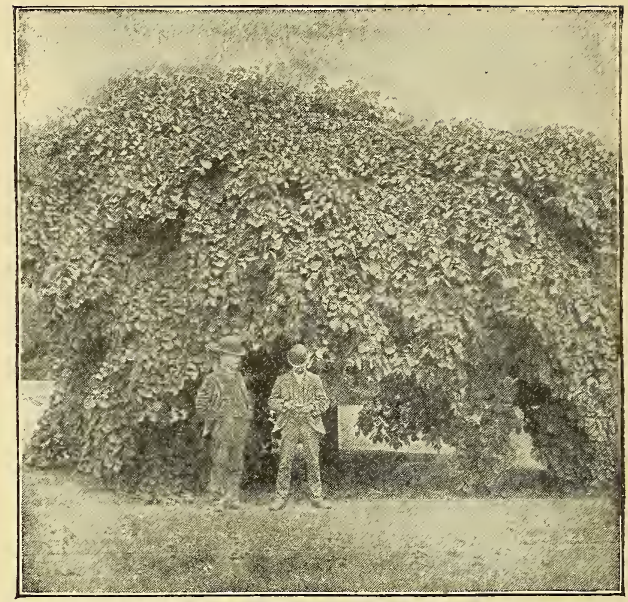

\section{Camperdown Elm. \\ Camperdown Elm.}

This old favorite is the largest of the "umbrellatopped" trees; foliage large, growth spreading and pendent. It produces dense shade and is the best arbor tree for lawns.

\section{American Elm.}

This well known tree ranks among the very best for avenue or park, especially in deep or wet soil. It grows rapidly and makes tough branches, rarely being damaged by wind or snow. Its spreading head, drooping branches and stately growth give it the name of the "Monarch of the Forest."

\section{Catalpa-Speciosa.}

This medium to large tree with its tropical-like foliage and its pyramids of white flowers is worthy a place in every collection.

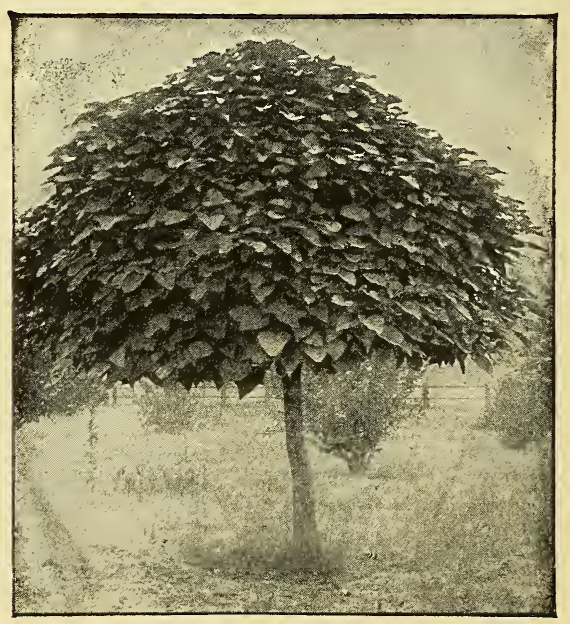

Catalpa-Bungei. 


\section{Carolina Poplar.}

This rapid growing tree, with its large glossy leaves, open head and symmetrical habit of growth, is the best of all poplars for shade and street planting. It retains its foliage later than other varieties and is well adapted to use in smoky cities. They may be allowed to branch to the ground when desired for windbreaks or screens.

\section{Catalpa-Bungei.}

A small species that grows $S$ to ro feet high and twice as broad, forming a great bush, clothed with a dense mass of large, heart-shaped leaves. Among our hardy shrubs there are but few, if any, that are more effective as foliage plants for park or lawn. When grafted on a stalk of one of the tree species 5 or 6 feet high, it makes a handsome standard tree, with a very dense and symmetrical globular head without trimming.

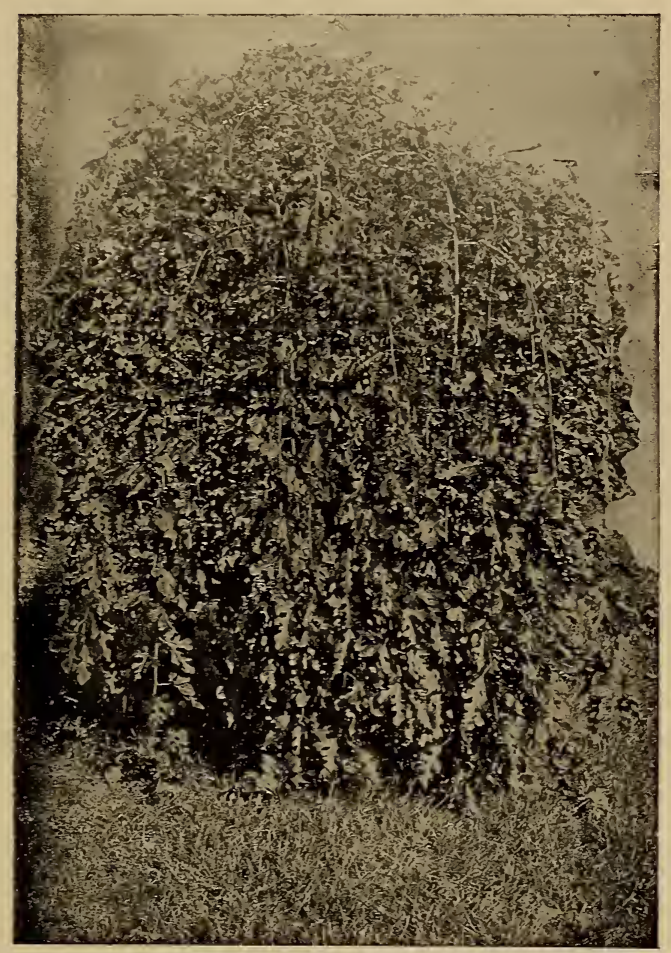

Teas' Weeping Mulberry.

\section{Weeping Mulberry.}

This new weeping tree is without doubt the best for general planting of all small lawn or cemetery trees. Its willowy, pendent branches are covered with large light green deeply lobed foliage. The tree is hardy and thrives in a variety of soils.

\section{Ash-leaved Maple, or Box Elder.}

Of rapid growth, especially while young, and spreading form; foliage small and of light green color. Transplants easily and does well in dry soil. A good shade tree, and if pruned attractive and valuable.

\section{Judas Tree, or Red Bud.}

A very pretty low-growing, round-headed tree, the stems of which are clothed with a profusion of purplish-red flowers before the foliage appears. Unique and beautiful. They flower at the same time as the Chinese Magnolia, and when planted near together the effect is most striking.

\section{Dogwood.}

White and red flowering dogwood are fine small growing trees of spreading, irregular form. Flowers are begonia-shaped, about three inches across, produced before the leaves and just as the Chinese Magnolia flowers are fading, and thus are valuable for maintaining a succession of bloom for the lawn or garden. One of the most valuable lawn trees, and should be planted in pairs, showing the contrasting colors. Autumnal foliage brilliant and beautiful.

\section{Thorn, Double Flowering.}

Among the small trees the thorns are classed as leaders, and grow more popular every year. They are dense and low in habit, showy in flower, resembling masses of miniature roses. Hardy and adapted to all soils. Especially valuable for small grounds. Flowers white and scarlet.

\section{Japanese Weeping Cherry.}

Among trees of drooping habit there are none more beautiful than these. Its beauty consists not only in its graceful, pendulous habit, but its copious production of beautiful flowers, with which its branches are covered during the blossoming season, producing a most charming spectacle. The foliage, too, is handsome and healthy. It is equally suited to both large and small places, but should be given plenty of room to display its beauty. No other drooping tree of recent introduction is so meritorious. Can be furnished in both white and rose-flowering.

\section{Cut-leaf Weeping Birch.}

This fine tree excels all others in its tall form and graceful beauty; its upright center trunk covered with white bark, its drooping branches and pendent leaves increase its attractiveness. It is hardy and thrifty in all locations.

\section{Japan Chestnut.}

This variety makes a highly ornamental tree, attaining a height of 30 feet. Nuts about 3 times as large as the American variety and of better quality than the Spanish. Commences to bear when 5 years old and not over 7 feet tall. Hardy.

\section{Helesia, or Silver Bell.}

A small tree bearing beautiful bell-shaped pure white flowers similar to the Snowdrop, but much larger. Blooms early. Grown in shrub form it is exquisite.

\section{Koelreuteria.}

A small growing round-headed tree from China, with pinnate leaves and large panicles of showy golden yellow flowers in July. An unusually good lawn tree and perfectly hardy. 


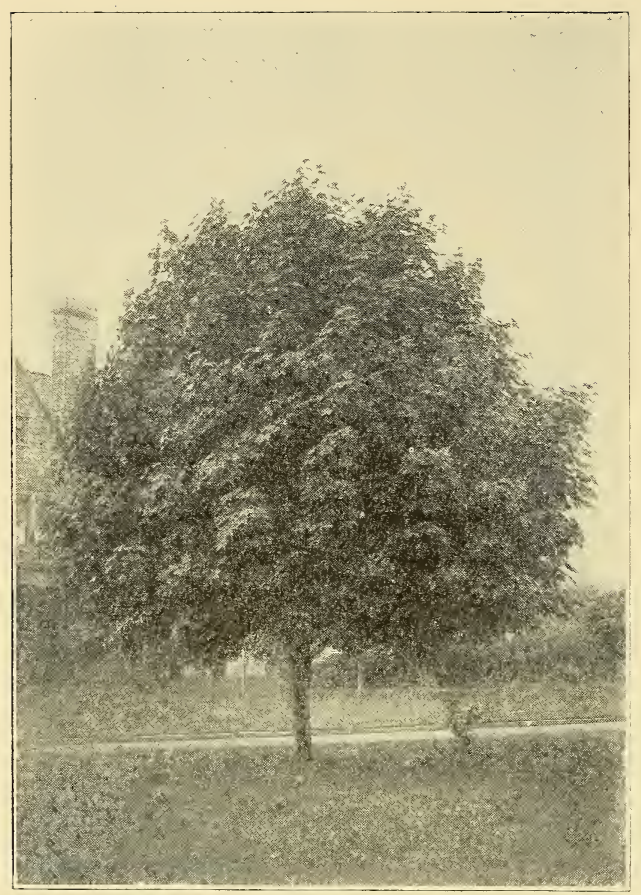

Schwedler's Maple.

\section{Japanese Maples.}

These slow, low-growing dwarfish trees are general favorites, on account of their dense, compact and graceful growth and brilliant, beautifully cut foliage, varying in color from brightest yellow to deep blood-red. Unsurpassed for lawn decoration. Autumn colorings are gorgeous.

\section{Schwedler's Maple.}

\section{NEW BROAD-LEAVED PURPLE MAPLE.}

One of the handsomest, most valuabie and popular of the new foliage trees. Its hardiness, easy growth, freedom from insects and disease, and clearly distinct and permanent color, make it especially desirable. In size and form of leaf and habit of growth this tree is very much like the Norway Maple described below. The foliage and leaf stalks, however, are different, being a distinct maroon red or a reddish purple color, quite permanent in mid-summer, and especially distinct in spring and autumn.

\section{Norway Maple.}

The dense, dark foliage of this lovely tree and its compact, strong habit of growth, its freedom from attacks of insects, combine to make this the very best street, avenue or lawn tree for all situations. It rivals the oak, and the oldest trees known are still young in appearance.

\section{Silver-Leaved or White Maple.}

A hardy, rapid-growing native variety of the largest size : foliage bright green above and silvery

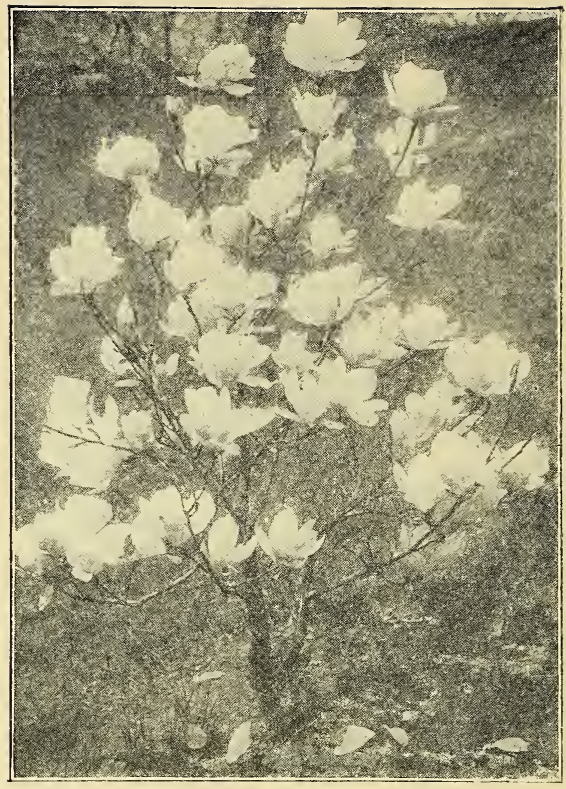

Magnolia Soulangeana.

Probably one of the most showy and popular of the Chinese varieties, and should be grown wherever they will stand the climate.

underneath. Valuable for producing a quick shade. Excellent for street planting. When fully grown, 50 to 60 feet.

\section{Wier's Cut-Leaved Silver Maple.}

This is one of the most remarkable and beautiful trees with cut foliage. Its growth is rapid, shoots slender and drooping, giving it a habit almost as graceful as the cut-leaved Birch. The foliage is abundant, silvery underneath, and on the young wood especially deep and delicately cut. The leaf stalks are long and tinted with red on the upper surface. It may be easily adapted to small places by an occasional cutting back, which it will bear to any degree necessary.

\section{Magnolia.}

A class of valuable and beautiful trees because of their fine foliage, luxuriant appearance and fragrant flowers. They are the best lawn trees in our collection where climate is suitable.

\section{AMERICAN VARIETIES.}

Acuminata (Cucumber Tree)-A magnificent native tree with large pointed leaves 6 to 9 inches long; blossoms green and yellow, 4 to 6 inches in diameter; fruit resembles a green cucumber.

Tripetela (Umbrella Tree)-A hardy, native medium sized tree, with enormous long leaves and large white fragrant flowers 4 to 6 inches in diameter, in June.

\section{CHINESE VARIETIES.}

These are the $d$ warf growing, large flowering varieties, of which the best are Speciosa and Soulangeana, white with red-purple centres, and Conspicua, pure white. 


\section{Palustris or Pin Oak.}

A tall, upright growing variety when young, but with age the branches droop. Foliage bright and glossy. One of the best oaks for street planting and becoming very popular.

\section{Rivers' Purple Beech.}

A variety of European beech with large, smooth, very dark leaves. The best purple lawn tree known.

\section{Cut-Leaved Beech.}

An erect, free-growing tree, foliage light green and deeply cut or incised. A fine lawn tree.

\section{Glyptostrobus Sinensis Pendula. Weeping Chinese Cypress.}

Very pendulous, with delicately cut foliage of pea green shade. An elegant tree; distinct and valuable.

\section{Linden.}

The American and European Lindens are our best large-leaved shade trees. Specially adapted to lawn planting. Foliage is dense, and when in bloom their fragrance is delightful.

The Lindens are all beautiful, and merit more notice than they receive. They possess many valuable qualities. See cut below.

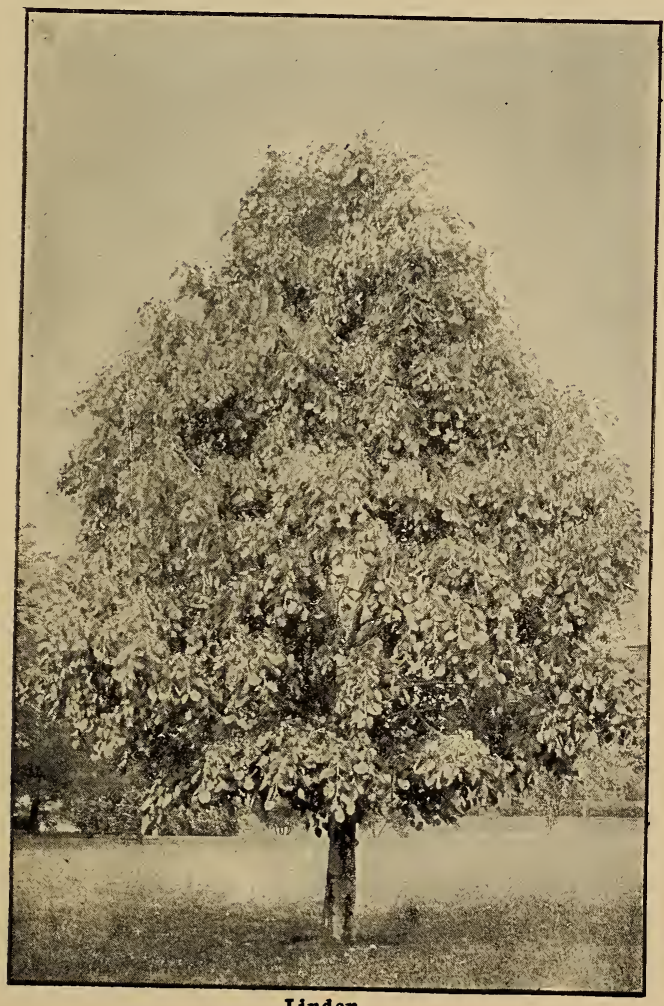

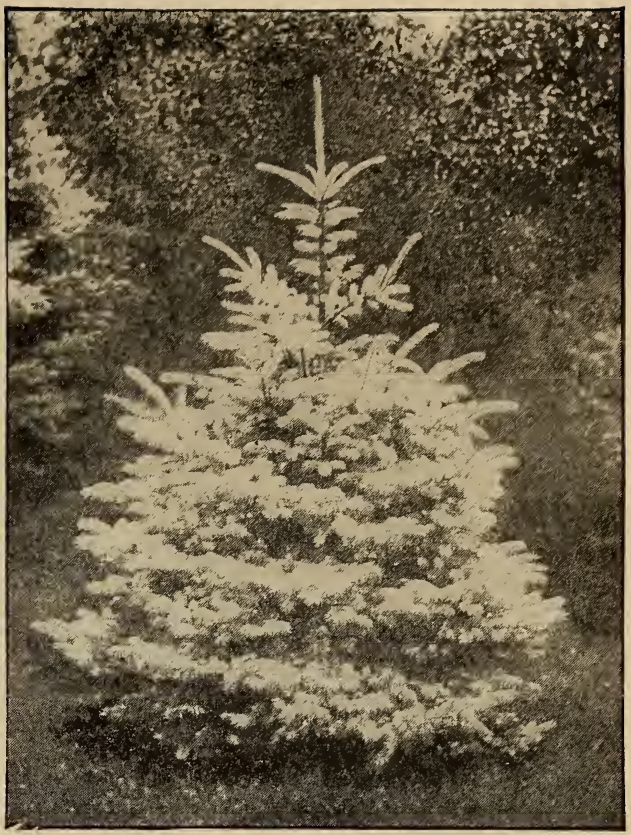

Colorado Blue Spruce.

\section{Black Locust.}

A native tree valuable for posts and timber and quite ornamental. The flowers are disposed in long pendulous racemes, white or yellowish, fragrant, and appear in June.

\section{Colorado Blue Spruce.}

This photograph is of a specimen about 20 feet high and gives a partial idea of this magnificent tree. This variety of Spruce was found in the Rocky Mountains, and wherever planted has given the greatest satisfaction, thriving well in all conditions of climate, proving entirely hardy, and is universally esteemed as the most beautiful of all evergreens. It will make a very large tree, but the best specimens are grown from quite small trees from the nursery. Florists should keep a stock of transplanted specimens in a conspicuous place.

\section{Laburnum or Golden Chain.}

A native of Europe, with smooth shining foliage, attaining the height of 20 feet. The name of Golden Chain alludes to the length of drooping racemes of yellow flowers, which, as Cowper elegantly describes them, are "rich in streaming gold." They appear in June.

\section{Sweet Gum or Bilsted.}

One of the best of our native trees. Its star-shaped leaves, glossy green in summer, take on in fall the most intense shades of purple, orange and crimson. Bark corky and growth stately. 


\section{Desirable Trees to Plant.}

\section{A LIST OF TREES RECOMMENDED FOR VARIOUS PURPOSES.}

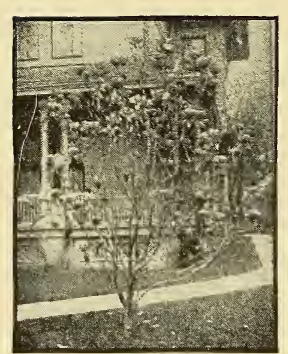

Magnolia Lennei.

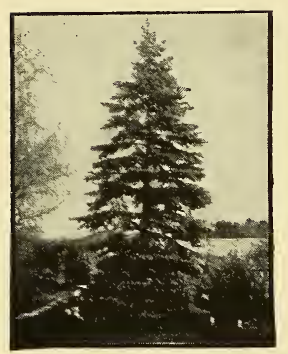

Norway Spruce.

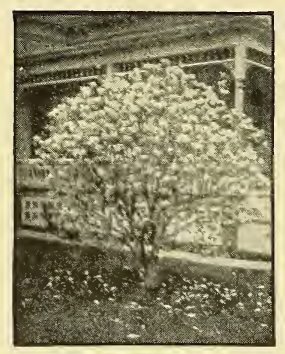

Chinese Magnolia.

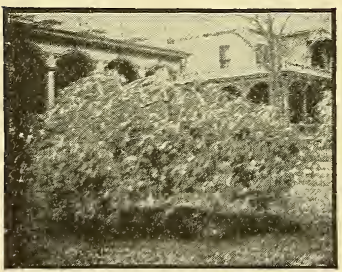

Weeping Mountain Ash.
For Streets, Roads and Wide Avenues.American Elm, Sugar, Sycamore and Silver Maples, Carolina Poplar, Pin Oak.

For Driveways through Lawns and Parks. -Norway Maple, Salisburia or Gingko, Tulip Tree, Magnolia Acuminata, Catalpa Speciosa, to which we add American and European Lindens.

Single Specimens of Large Growth.-English and Rivers' Beech, Birches, particularly CutLeaf Weeping; English and Purple-Leaf Elms; American, European and White-Leaf Lindens; Norway, Purple Norway, Sycamore and Cut-Leaf Maples; Horse Chestnuts; Austrian and Scotch Pines; Norway and Colorado Spruces.

Single Specimens of Medium Growth.Imperial Cut-Leaf Alder, Fern-Leaf and Weeping Beech, Catalpa Bungei, Purple Birch, Horse Chestnuts, Laburnum, Chinese Magnolias, OakLeaf Mountain Ash, Prunus Pissardi, Flowering Thorns, Hemlocks, White Pines, Siberian Arborvitæs, etc.

Strong-Growing Trees of Pyramidal Habit.-Lombardy and Bolleana Poplars.

Trees that thrive in Moist Locations.American Elm, American Linden, Ash, Catalpas, Poplars and Willows.

Trees that thrive on Dry Knolls of Poor Soil.-Silver-leaf and Ash-leaf Maples and Poplars.

Best Trees for Wind Breaks. - Norway Spruce (evergreen), Carolina Poplars and Silver Maples.

Flowering Trees,-Magnolias, white and purple ; Judas Trees, Peach, pink and white; Laburnum, yellow ; Fringe Tree, white and purple ; Lindens, Horse Chestnut, red and white; Cherry, white ; Catalpa, Thorns, pink, scarlet, red, white.

Cut-Leaved Trees.-Imperial Cut-Leaved A1der, Fern-Leaved Beech, Cut-Leaved Birch, Wier's Cut-Leaved Maple.

Purple and Scarlet-Leaved Trees,-Purple-Leaved Beech, Purple-Leaved Birch, PurpleLeaved Elm, Prunus Pissardi, Purple Norway and Sycamore Maples, Japan Maples.

Weeping or Pendulous Trees.-Ash, Beech, Birch (Cut-leaved and Young's), Cherry (Dwarf and Japanese), Crab, Cypress, Dogwood, Elm (Camperdown), Linden (White-leaved), Maple (Wier's), Mountain Ash (European), Mu1berry ('Teas'), Willow (Babylonica, Kilmarnock, New American and Wisconsin).

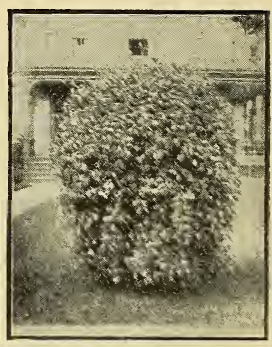

Kilmarnock Willow.

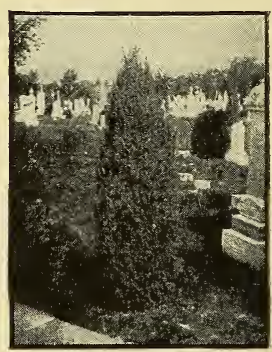

Irish Juniper.

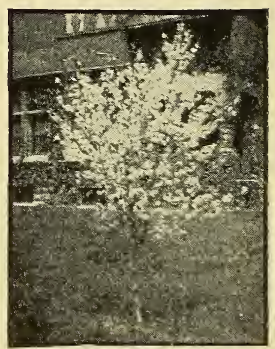

Dble-Flowering Peach. 


\section{* * SHRUBS. * * *}

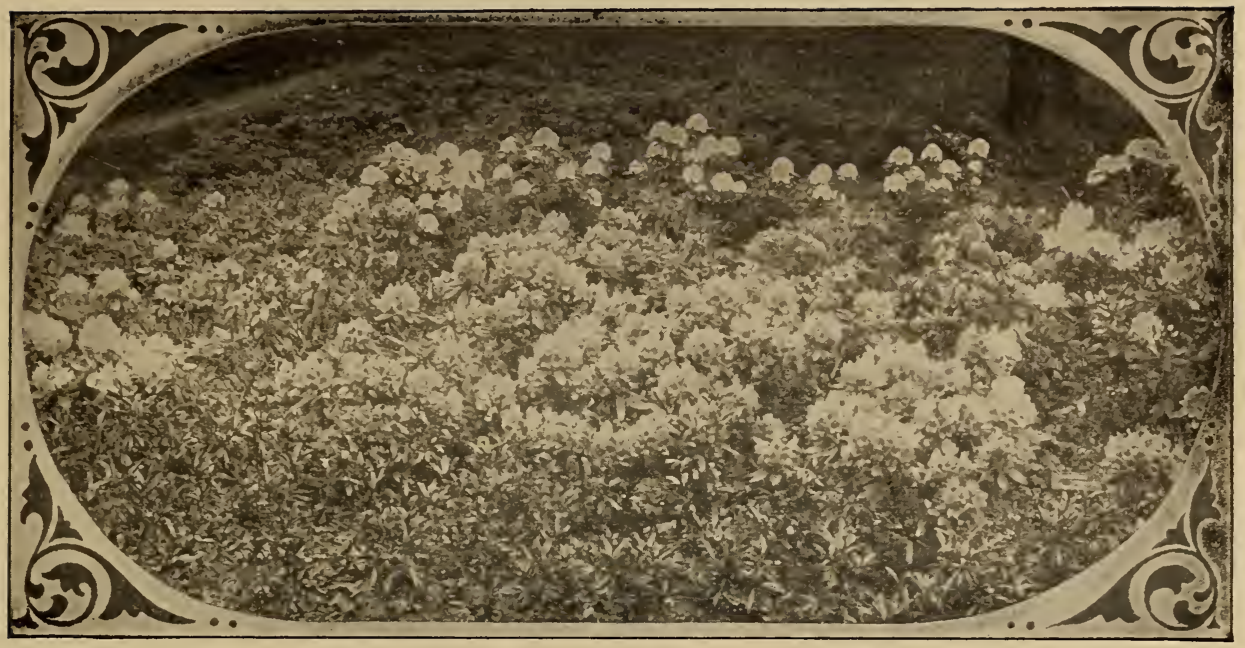

BED OF RHODODENDRONS.

It is useless to dwell upon the beauties of this magnificent evergreen shrub. All are familiar with its broad, glossy, dark-green foliage and superb trusses of showy flowers of gorgeous tints and colors.

CULTURE.-They flourish best in peaty soil and, like azaleas, are most effective when gronped. In preparing a bed, if possible, locate it where it will be partly sheltered from the intense heat in summer and from cutting winds in winter. The bed should be prepared with old sod, old manure and sand or, better still, if obtainable, good leaf mould, which prevents the fine hair-like roots from drying out in hot summer weather, from which cause many plants are lost. Heavy mulching in summer is an excellent preventative, and in dry weather the beds should be thoroughly soaked. Pinch off all seed pods after flowering in order to get good buds for next season. In the fall mulch the beds a foot or more with leaves, and if these can be left to decay, it is advisable to do so.

\section{Spireas.}

Anthony Waterer.

A new dwarf shrub of great beauty. Its broad Bat heads of red flowers continue in perfection many months. Bumalda (pink) and Callosa Alba (white), have the same form and the three make a beautiful combination.

Thunbergii.

A Japanese species of small size, with narrow linear leaves and small white flowers; one of the best. Very effective for grouping.

Van Houttei.

The best white Spiræa. The annual growth is long and abundant and covered in June with a wealth of pure white blossoms in a perfect cascade of bloom. Perfectly hardy. Should be in every collection.

\section{Hydrangea Paniculata Grandiflora.}

This is undoubtedly the best and most effective shrub for all locations, and the tree form of this well known, late blooming shrub, as it attains age, becomes conspicuous and beautiful beyond तescription.

\section{Hydrangea Arborescens Sterilis.}

This variety of Hydrangea is taking the place in public favor held by Hydrangea Paniculata Grandiflora. It is perfectly hardy and of easy culture. The flowers are purer white, large, borne in as great profusion, and remain well into the winter.

\section{Exochorda. Grandiflora.}

A rare and beautiful shrub from China. Hardy and easily transplanted; of compact growth, and can be trimmed in dwarf form if desired. Pure white flowers, somewhat resembling the Syringa, but appearing on longer and lighter spikes. Blooms in May about the time of Lilacs and Rhododendrons.

\section{Althea.}

Vast improvements have been effected in this variety, and in consequence its old time popularity has been revived. It can now be supplied in a great variety of colors, and also in tree form, which shows off its large brilliant flowers to great advantage, making a very striking object for the lawn.

\section{Deutzia.}

A hardy class of plants of fine rather dwarf habit, luxuriant foliage and greatest profusion of attractive flowers, rendering them the most desira. ble of flowering shrubs. The most popular are PRIDE OF ROCHESTER, producing large double white flowers, the back of the petals being slightly tinted with rose; GRACIIIS, or SIENDER BRANCHED, a charming species with pure white flowers and fine for pot culture; LEMOINE, the newest and perhaps the finest of the family, the branches being entirely covered with pure white flowers of exquisite form. 


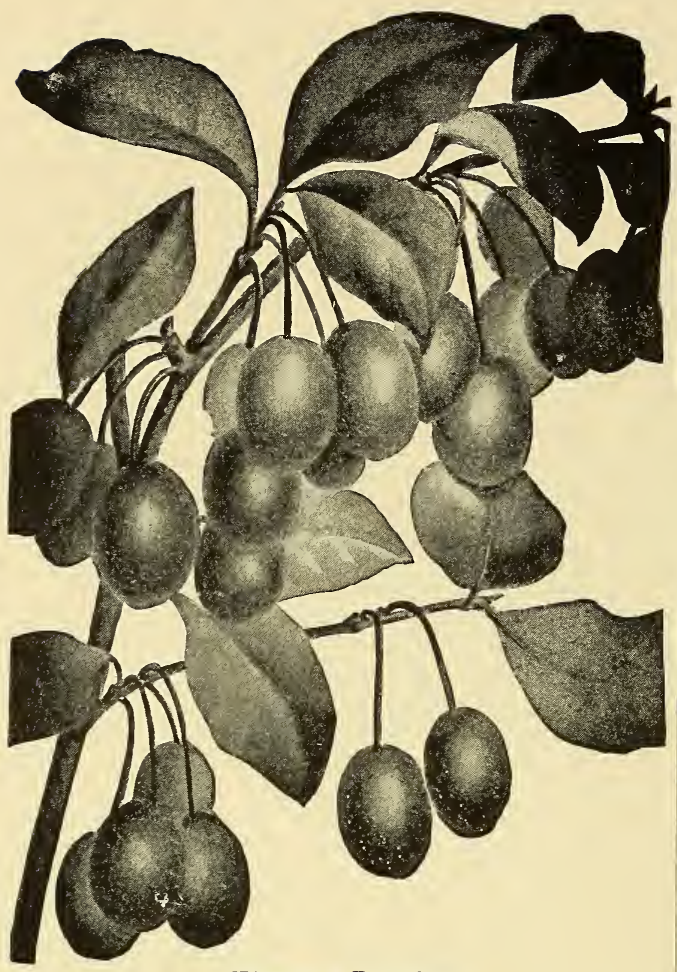

Eleagnus Longipes.

\section{Eleagnus Longipes.}

A handsome, shapely, silver-leaved shrub, with ornamental reddish-brown bark in winter; perfectly hardy and easy to grow. The bright yellow flowers appear in June on long stalks, but the greatest value of the shrub is in the fruit, which is produced in the greatest abundance along the whole length of the branches; oval in shape and about one-half inch long. Color deep orange red; very showy and attractive. The fruit is not only very ornamental, but has a sprightly, sharp, pleasant flavor, and makes a delicious sauce when cooked. Eleagnus is one of the most valuable ornamental berry-bearing shrubs, and should be largely planted.

\section{Barberry.}

\section{Thunbergii.}

One of the most effective plants in autumn, after most other deciduous shrubs are bare. Its small oval leaves then assume superb crimson hues, and the si nnder branches droop beneath their load of bright red berries, which hang on till late in winter. The bush is very thorny and is one of the best plants for low ornamental hedges.

\section{Xanthoceras.} Sorbifolia.

A large growing shrub or small tree from China, foliage similar to Mountain Ash. The flowers are about the size of cherry blossoms and white, with a coppery-colored eye and borne in clusters in great abundance.

\section{Lilac.}

These old-time favorites have again sprung into wonderful popularity, and justly so, as wonderful improvements have been made in both form and coloring, and they are now one of our most attractive classes of large growing shrubs.

$$
\text { Japan Tree Lilac. }
$$

A new species from Japan. Leaves thick, pointed, leathery and dark; flowers in very large pani. cles, creamy white and privet-like. Makes a small tree and is desirable because of its distinct foliage and late blooming.

\section{Cornus, or Dogwood.}

These are fine, large growing shrubs for planting singly, in groups or for massing, being distinguished for their elegant variegated foliage or their bright colored barks.

\section{Weigela.}

These are among the finest of the Japanese flowering shrubs, forming large symmetrical bushes with a drooping tendency, covered in June and July with large trumpet-shaped flowers of varying colors, while some have variegated foliage.

\section{Purple-Leaved Filbert.}

A very conspicuous shrub, with large, dark, purple leaves; distinct and fine. It is to shrubs what Purple Beech is to trees. Color good all the season.

\section{Cut-Leaved Sumach.}

A hardy plant of moderate size with large beautiful fern-like leaves, milky white on under side, changing to a brilliant scarlet in autumn.

\section{Japan Snowball.}

Handsome plicated leaves; globular heads of pure white neutral flowers, early in June. It surpasses the common variety in several respects. Its habit is better, foliage much handsomer, flowers whiter and more delicate. One of the most valuable flowering shrubs. These can also be supplied in tree form and are very effective.

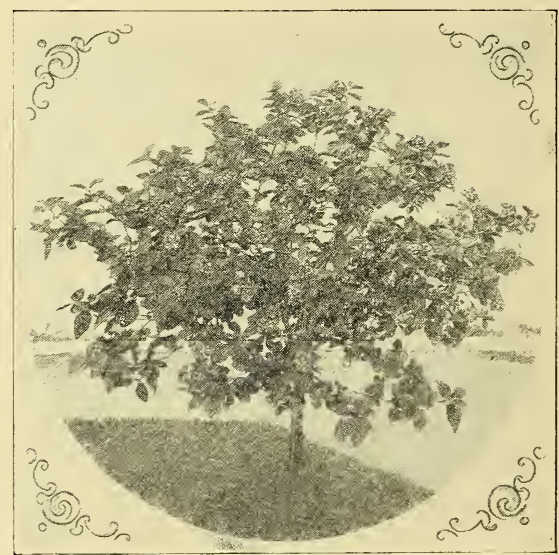

\section{High Bush Cranberry.}

Both ornamental and useful. Berries resemble cranberries; esteemed for sauce, tarts and jams. Berries hang on the bush until late in the fall. 


\section{CLIMBING VINES.}
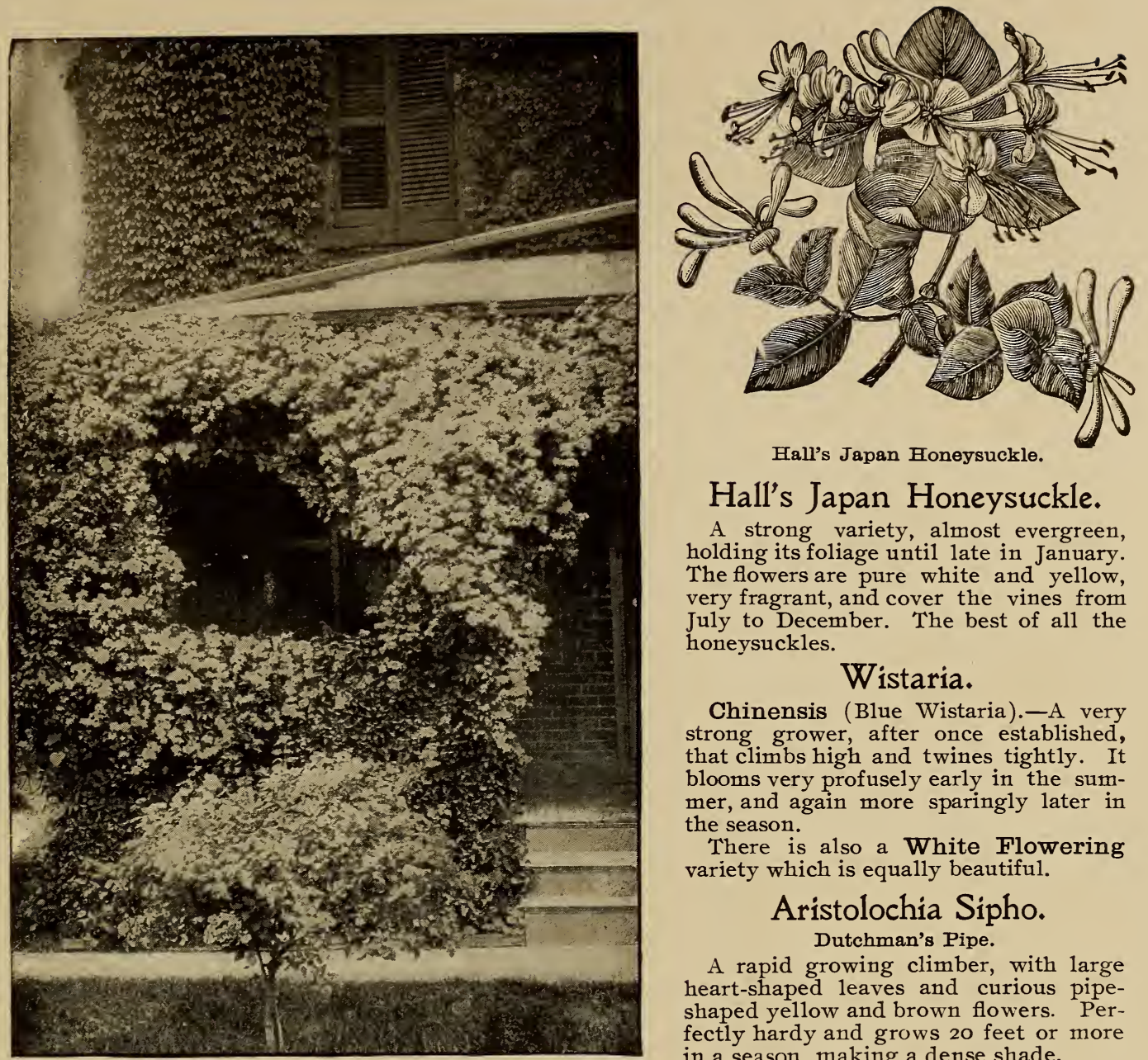

Hall's Japan Honeysuckle.

A strong variety, almost evergreen, holding its foliage until late in January. The flowers are pure white and yellow, very fragrant, and cover the vines from July to December. The best of all the honeysuckles.

\section{Wistaria.}

Chinensis (Blue Wistaria).-A very strong grower, after once established, that climbs high and twines tightly. It blooms very profusely early in the summer, and again more sparingly later in the season.

There is also a White Flowering variety which is equally beautiful.

\section{Aristolochia Sipho.}

Dutchman's Pipe.

A rapid growing climber, with large heart-shaped leaves and curious pipeshaped yellow and brown flowers. Perfectly hardy and grows 20 feet or more in a season, making a dense shade.

Clematis Paniculata on porch with Ampelopsis Vetchii above.

\section{Clematis Paniculata.}

A new vine of rapid growth suitable for covering trellises with glossy green. The small white flowers cover the plant in autumn with a "sheet of bloom."

\section{Clematis Mme. Baron Veillard.}

A new variety, much like the popular Jackmanni, except the flowers are a most unique shade of soft pink. A perfect gem.

\section{Ampelopsis Veitchii.}

\section{Boston or Japan Ivy.}

This variety which came from Japan in 1868 has found great favor throughout this country, and may be seen as a carpet of green on brick and stone walls all through the summer months. It adheres without nailing to brick or stone.

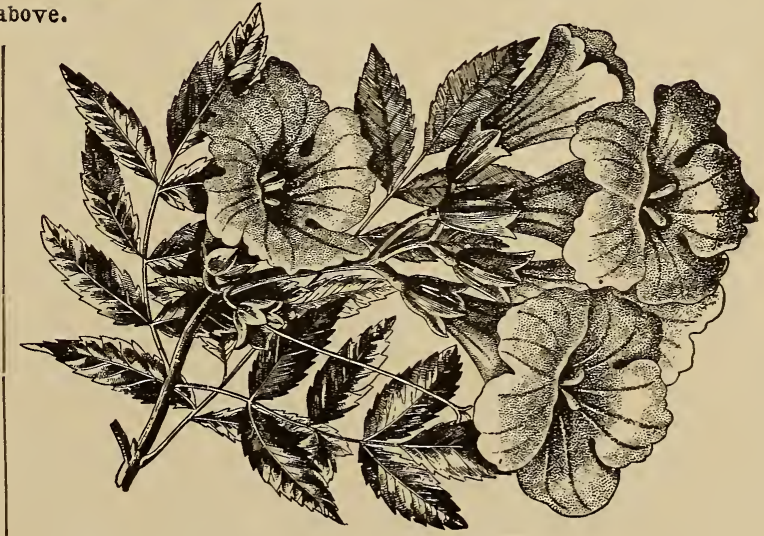

Bignonia, or Trumpet Flower.

$A$ vigorous and hardy climber, with clusters of scarlet trumpet-shaped flowers in August. 


\section{A List of the Best Shrubs}

With Colors of Flowers.

Althea-DOUBLE FLOWERING, red, white, purple and blue.

Barberry-PURPLE-LEAVED, yellow blossoms, red berries.

THUNBERGII, dwarf, red berries.

Caryopteris Mastacanthus- "Blue Spirea," blue.

Calycanthus-Maroon, very fragrant.

Cydonia Japonica-(Japan Quince), scarlet.

Currant-Yellow and crimson.

Cranberry-HighвusH, white flowers, red berries.

Deutzia-CRENATA, Fl. Pl., pink.

DOUBLE WHITE-FLOWERING, white.

GRACILIS, dwarf, white.

LEMOINE, white.

PRIDE OF ROCHESTER, white tinged with rose.

Elder-(Sambucus) VARIEGATED, foliage white.

AUREA, light yellow, golden foliage.

Eleagnus-LONGIPES, flowers creamy, fruit red.

Exochorda-Grandiflora, white.

Forsythia-VIRIDISSIMA, FORTUNEII and SUSPENSA, yellow.

Hydrangea-OTAKSA and RED BRANCH, rose. PANICUlati GrandifLoRA, white.

Thomas HogG, white.

Honey suckle-White, yellow and pink.

TARTARIAN, red, pink and white.

Kerria Japonica-VARIEGATED and SINGL,E, white and yellow.

Lilac-COMMON PURPLE and WHITE.

CHARLES X, reddish-purple.

JosIKEA, lavender.

PERSIAN, white and purple.

PRESIDENT GREVY, blush.

TREE (Japonica), creamy white.

Purple Fringe-or Smoke Tree, reddish-purple.

Prunus-Triloba, rose.

PISSARDI, reddish-purple leaves.

Sumach-CUT-LEAVED, fern-like foliage.

Spirea-ANTHONY WATERER, new, red.

AUREA (Golden), cream, yellow foliage.

BILLARDI and DougLAS, rose-pink.

BUMALDA, pink.

CAllosa Alba, white.

PRUNIFOLIA, double white.

REEVESI, white.

THUNBERGII, dwarf, white feathery foliage.

VAN HOUT'TEI, white.

Strawberry Tree-EUONymus, red and white fruited.

Snowball-White.

Syringa-(Philadelphus), white.

Waxberry-or SNOwBERRY, white and red fruited.

Tamarix-AFRICAN, pink.
Weigela-AMABILIS, pink.

Candida, white.

DESBOISII, dark pink.

EvA RATHKE, brilliant crimson.

FLORIBUNDA, dark maroon.

HORTENSIS NIVEA, pure white.

ROSEA, rose.

VARIEGATED-LEAVED, pink.

White Fringe-White.

Xanthoceras Sorbifolia-White.

\section{Climbing Vines.}

Aristolochia Sipho-Dutchman's Pipe.

Ampelopsis-VEITCHII.

VIRGINIA CREEPER.

Akebia Quinata-Purple.

Tecoma-Radicans (Trumpet Flower), red.

Celastrus-SCANDENS or BITTER SWEFT, red berries.

Cinnamon Vine-White.

Matrimony Vine-CHINESE, purple, scarlet berries.

Clematis-LARGE FLOWERING.

COCCINEA, red, and CRISPA, lilac color.

JACKMANNI, purple. Well known; popular.

HENRYI, white. The best white.

MAD. EDOUARD ANDRE, red.

PANICULATA, fine white flowers, late.

VIRGINICA and FLAMMUL,A, white flowers, July.

Honeysuckle-AUREA, golden-leaved.

BELGICA, Monthly Fragrant, red and yellow.

CaINESE TwINING, white.

HALLEANA Or HALL'S JAPAN EVERGREEN.

SCARLET TRUMPE'T.

YELLOW TRUMPET.

IVy-ENGLISH.

Wistaria-CHINESE PURPLE.

CHINESE WHITE.

MAGNIFICA, blue.

\section{Deciduous Shrubs.}

Flowering Shrubs-Variegated or Colored FoliageAlthea Variegated; Filbert; Barberry, Corchorus, Dogwood, Elder, Golden, Eleagnus Longipes, Prunus Pissardi, Syringa Variegated; Weigela Variegated.

Shrubs that flower in May-Almonds, Forsythia, Honeysuckle, Japan Quince. Lilacs, Exochorda, Prunus Triloba, Snowball, Spirea, Tree Pæonia, Wistaria.

In June-Akebia, Clematis, Deutzia, Dogwood, Elder, Eleagnus Longipes, Honeysuckle, Lilacs; Pæonias, herbaceous; Rhododendrons, Snowballs, Spireas, Syringa, Weigela, Wistaria.

In July-Clethra, Clematis, Spirea, Honeysuckle.

In August and September-Althea, Bignonia, Clematis, Honeysuckle; Hydrangea Paniculata Grandiflora.

Shrubs whose flowers are succeeded by ornamental fruit-Barberry, scarlet berries in September; Chinese Matrimony Vine, red berries; Dogwood (Red-Branched), white berries in September; Iogwood (Cornelian Cherry), red berries in August; Elder, purple fruit in August; Eleagnus Longipes, deep orange red berries, very showy; Highbush Cranberry; Strawberry Tree, red fruit; Mahonia. bluish berries in July. 


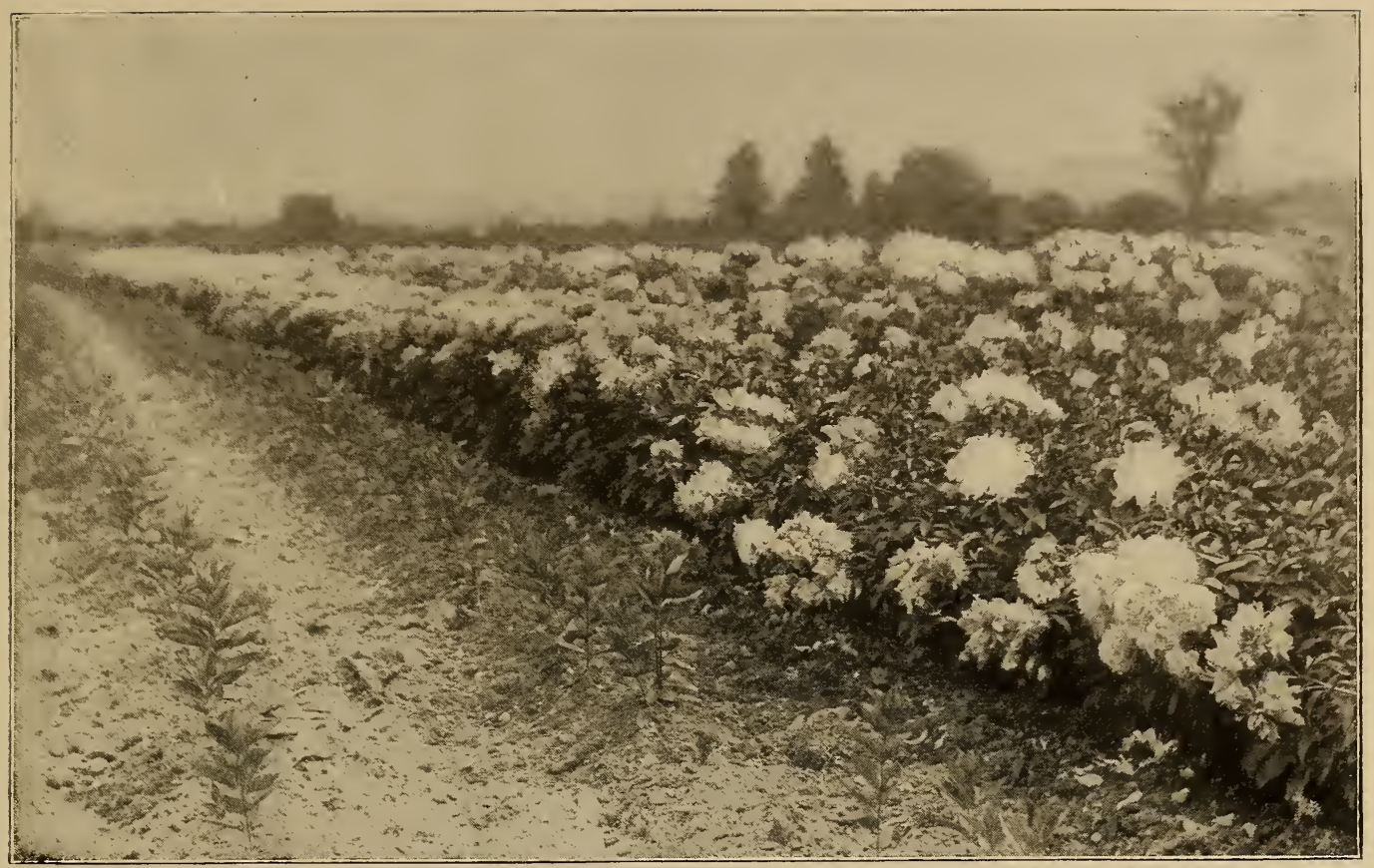

Showing a block of Paeonias in the Nursery. This effect may be produced by planting in large beds on the lawn or in front of shrubbery.

\section{PAEONIA}

One of the chief points in favor of the pæonia is its hardiness. In the severest climate the plants require no protection. Their vigorous habit, healthy growth, freedom from disease and insects are in favor of their cultivation. When the pæonia is once planted, all that is necessary has been done; they require no further care, and each succeeding year adds to their size and beauty. The foliage is rich and glossy, and of a beautiful deep green color, thus making the plants highly ornamental even when they are not in flower. The pæonia can be planted either singly, on the lawn, or it can be used to excellent advantage to plant as a border line between lots. A large bed makes a most magnificent appearance. The pæonia is the flower for the many, and a selection of sorts will give continuous bloom from May to July, and in every shade of color from pure white to dark purplish crimson. We have a large and fine line to select from.

Pæonia, Moutan.-Flowers of enormous size. Color, rosy pink. Very effective.

Fringe Leaf Pæonia (Pæonia Tenuifolia).A remarkable and strikingly beautiful variety with delicate fern-like foliage and double scarletcrimson flowers, very brilliant and satiny. Perfectly hardy.

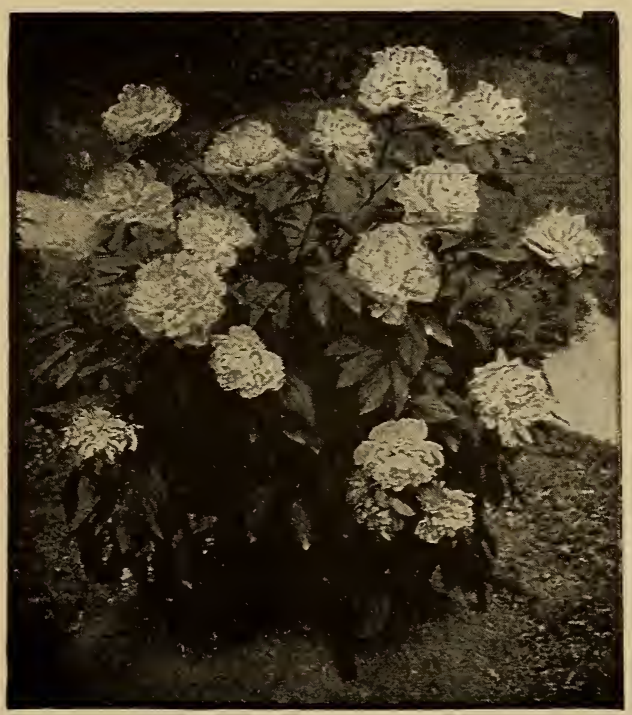

Herbaceous Paany. 


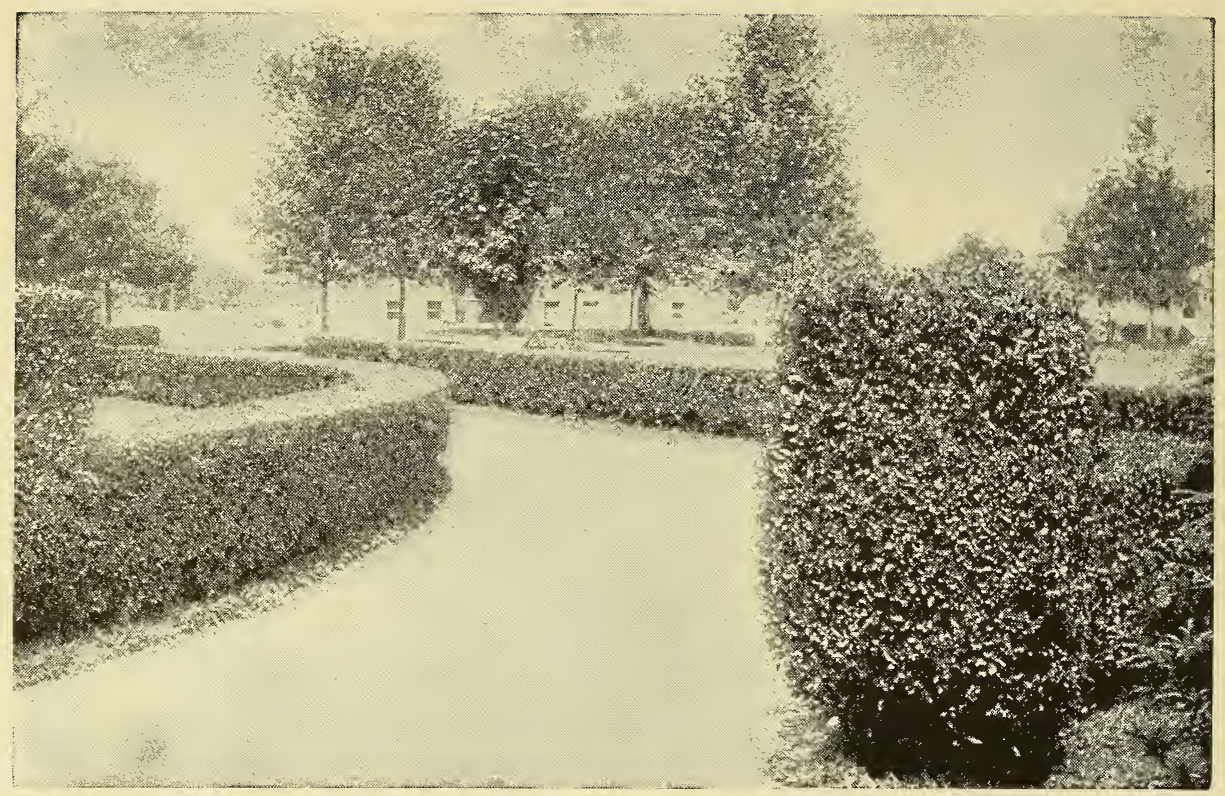

Privet Hedge

\section{Hedge Plants.}

To screen unsightly objects from view, to mark lines of boundaries, hedges are most useful, and with proper attention very ornamental.

For permanent all-round effect evergreens are desirable, and the best sorts for the purpose are Hemlock Spruce, American Arborvitæ in variety, Norway and other Spruces. These can be allowed to grow at will or kept in any desired shape by shearing.

Among deciduous shrubs for ornamental hedges the Privet is very popular, having a

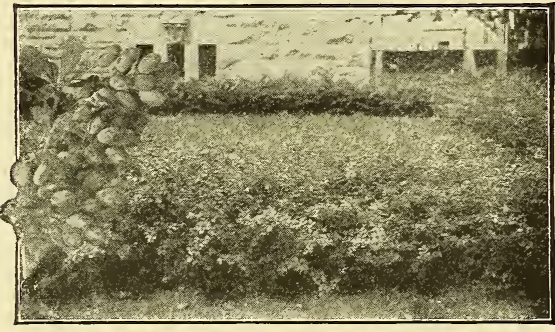

Thunberg Barberry Hedge, Untrimmed.

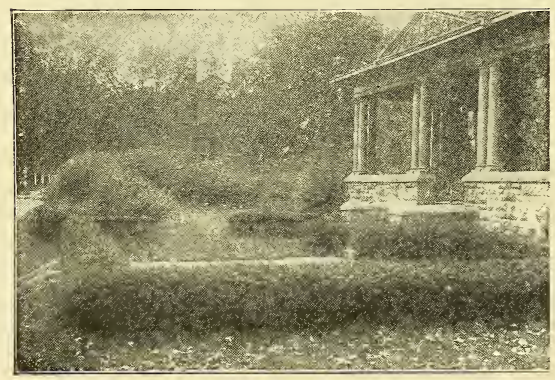

Privet Hedge, Trained Low. foliage of great beauty and permitting a shearing to an extent that would ruin most plants. But in certain situations and for certain uses there is another even better, the Berberis Thunbergi, which for a low hedge has no equal.

This beautiful species from Japan, with round droop. ing habit, spoon-shaped leaves of fine brilliant green in summer, takes on from early autumn till December the most glowing colors of any shrub or tree-crimson orange, bronze and green, with all the intermediate shades, blended in the foliage of a single bush, the effect being most extraordinary and beautiful. After the leaves fall the branches are seen to be loaded down with scarletcrimson berries, and these often hang until April, presenting a most beautiful object, and is also of great value to plant as "cover" where quails or other game birds are protected, as they feed greedily on its seeds. For a hedge 3 to 4 feet high it is the very best of all plants, being impenetrable, as it is thickly set with spurs.

No other plant so fully meets every requirement of a hedge, combining beauty in all seasons, hardiness, compact growth, impenetrability and ease with which it may be kept in proper form.

We urge all intending to plant hedges to thoroughly prepare and enrich the soil, if of poor quality. We grow large quantities of these standard plants and will make very reasonable quotations. 


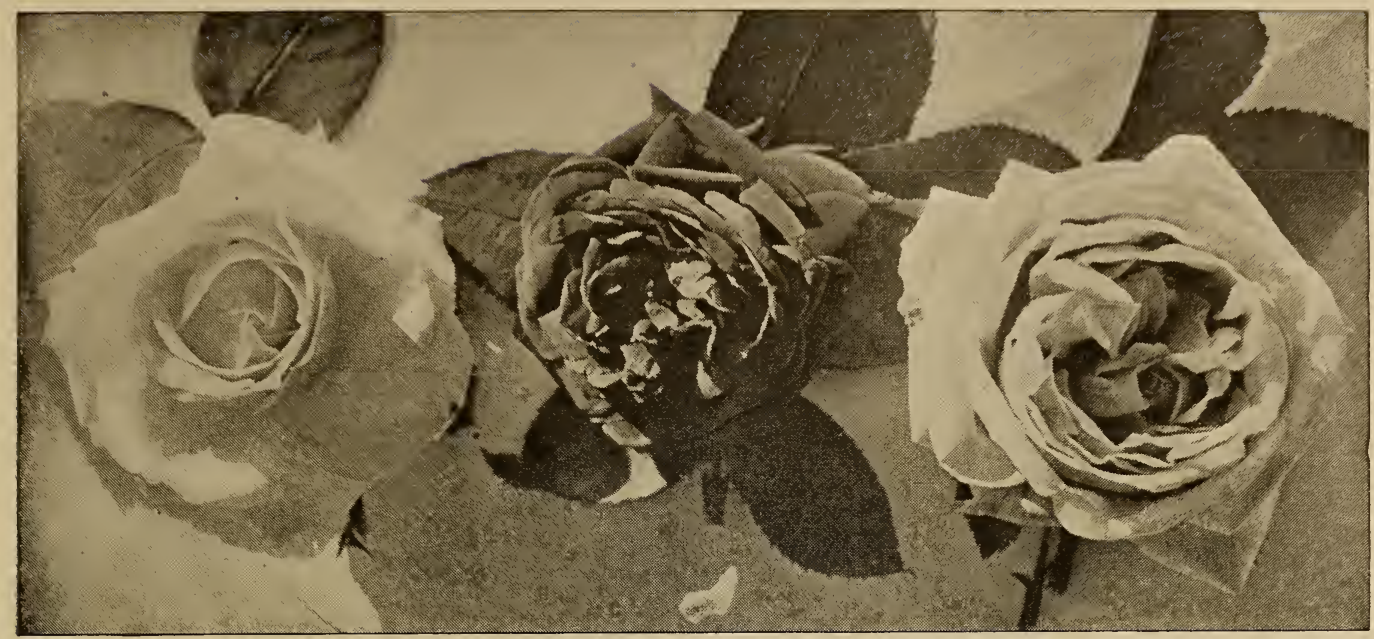

Clio.

Madame Gabriel Luizet.

\section{ROSES.}

\section{Rosa Rugosa.}

A rare and valuable species of rose, quite distinct from any of the familiar garden varieties in foliage, flower and fruit. It is a particularly attractive bush, covered with a dense mass of large, glossy, aromatic leaves, which have a peculiar wrinkled appearance. The large, single flowers are very showy, fine rosy-red or white, and are followed by bright scarlet fruit as large as small crab apples.

\section{Crimson Rambler.}

For a climbing rose the new Crimson Rambler excels all others. Foliage dark green: flowers in large clusters of small semi-double bright crimson, covering the plant for a long season with a "gorgeous sheet of bloom"

This Japanese rose has been tried in all situations and has proved to be one of the best roses ever produced. We cannot recommend it too highly It can be trained to a trellis or pillar.

\section{White, Yellow and Pink Ramblers}

are new climbing roses of fine habit and foliage, somewhat similar to Crimson Rambler.

\section{Marchioness of Londonderry.}

Flowers of great size, perfectly formed and carried on stout stems. Color ivory-white, petals of great substance, shell-shaped and reflexed. Highly perfumed and free flowering. Foliage handsome and healthy

\section{Margaret Dickson.}

Of magnificent form; white, with pale flesh center; petals very large, shell-shaped, and of great substance ; fragrant, a very beautiful variety; foliage very large, dark green.

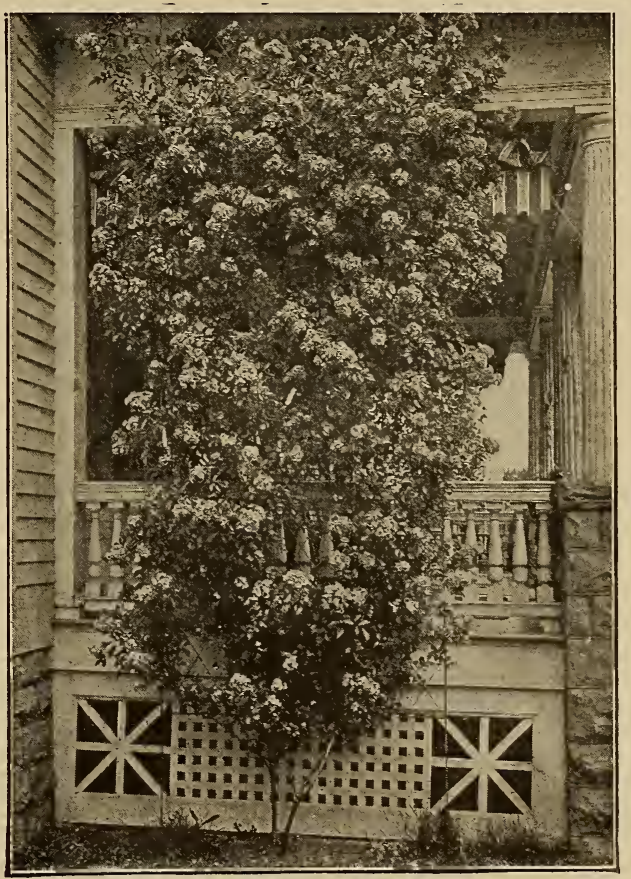

Crimson Rambler.

\section{Earl of Dufferin.}

One of the finest roses of recent years; red and velvety crimson, shaded with dark maroon. Large flowers, finely formed, vigorous grower. One of the very finest dark roses. 


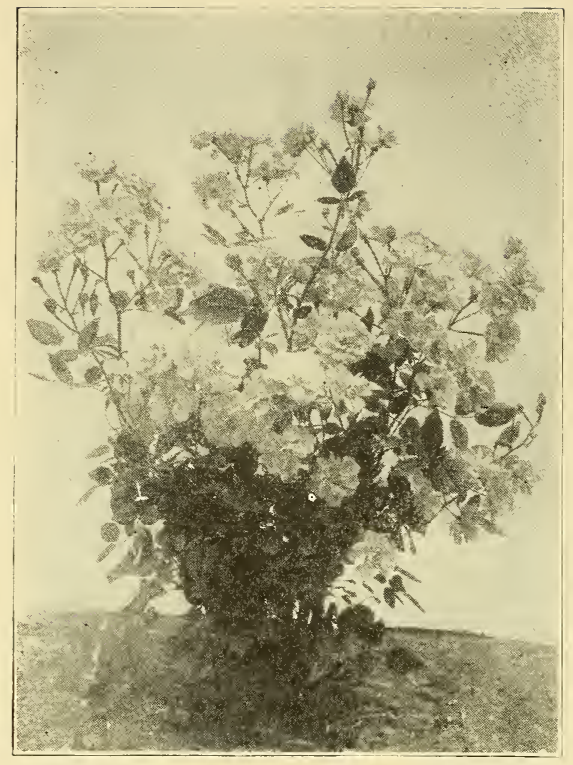

Pink Baby Rambler.

\section{Pink Baby Rambler.}

This magnificent Baby Rambler is equally as meritorious as the Crimson Baby Rambler, which has become so famous. Of dwarf growth, it blooms practically all the time, producing in amazing quantities large clusters or panicles of its beautiful pink flowers, which are full and double; color almost identical with the Dorothy Perkins.

\section{Crimson Baby Rambler.}

\section{(Madam Norbert Levavasseur.)}

The new ever-blooming Dwarf Crimson Rambler. In this new variety we have the wonderful Crimson Rambler reproduced in dwarf or bush form, with this added quality that the Baby Rambler is a ceaseless bloomer. Indoors it may be kept in flower all the year round, and out-of-doors it blooms continuously from June till after late frosts. In addition to the foregoing these may be had in pink and white, known as Pink Baby and White Baby Ramblers. Very desirable for bedding and borders.

\section{Marshall P. Wilder.}

The best rose of its color and class, a vigorous grower, flowers large, full and well-formed and very fragrant. Color cherry carmine. It blooms as early as any other H. P. and continues through the season.

\section{Paul Neyron.}

Flowers of immense size; one of the largest roses grown and one of the finest; color deep shining rose, very fresh and pretty. It is a strong grower and remarkably free bloomer.

\section{Clio.}

This is a grand addition to our list of white or blush hardy garden roses. The flower is perfection in form, with fine broad petals; color delicate satiny blush, with a light shading of rosy-pink at the center. It is doubtful if this beautiful rose will ever be outclassed by one of its color.

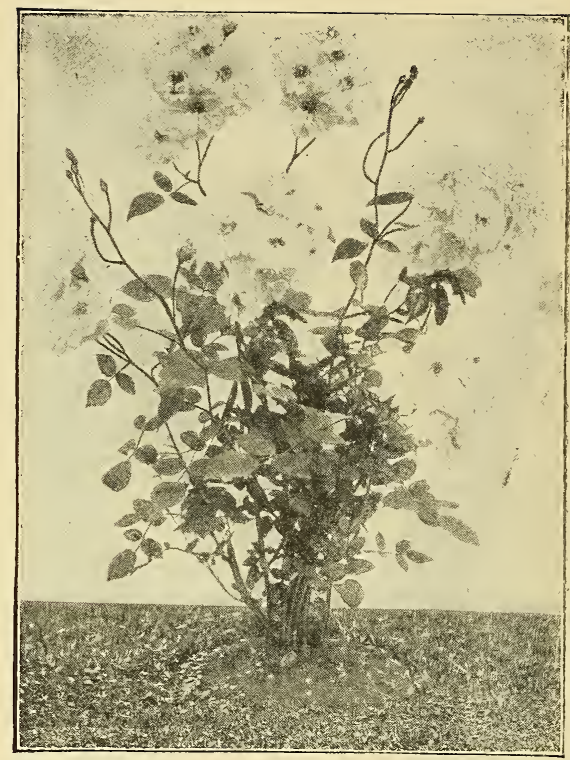

White Baby Rambler.

\section{White Baby Rambler.}

This is a Polyantha rose, and is a very interesting variety. Of free growth, producing perfectly double, pure white flowers $I \frac{1}{2}$ inches in diameter, in great profusion. It is delightfully fragrant, having the perfume of hyacinths. It will become a popular variety.

\section{Madam Gabriel Luizet.}

A fine satiny rose, inlaid with silvery-rose, heightened at the center. One of the most beautiful roses grown. A strong, sturdy grower.

\section{Mrs. John Laing.}

This lovely satiny-pink rose proves to be a most desirable variety. It is large and of fine form and flowers continuously, deliciously fragrant, and valuable for forcing or garden culture.

\section{Teplitz.}

A splendid sort; bright clear crimson; very sweet; flower fine form; very showy; a free bloomer.

\section{General Jacqueminot.}

This lovely rose is seldom if ever omitted from any collection, and will ever be a favorite. Its clear, rich, brilliant crimson-scarlet color, large and elegant form, free flowering habi and strong erect growth, all combine to captivate the heart of every lover of the beautiful. Perfectly hardy.

\section{Prince Camille de Rohan.}

Deep velvety crimson; large; moderately; full. 


\section{Other Fine Roses.}

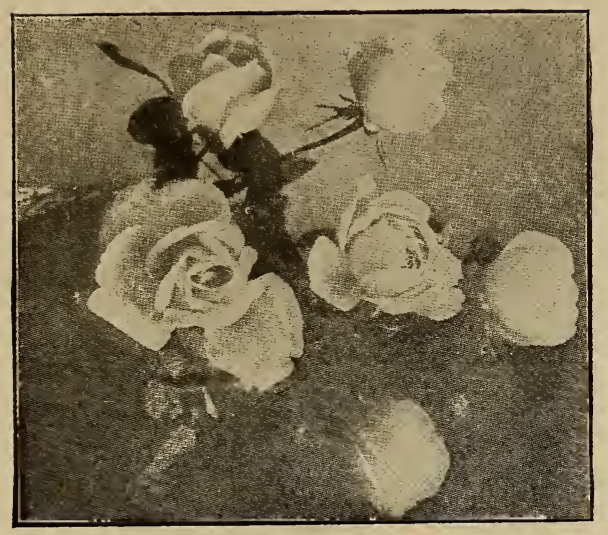

HARDY HYBRID PERPETUAYS.

Alfred Colomb, carmine crimson.

Anne de Diesbach, pink.

Baron de Bonstetten, velvety maroon.

Caroline de Sansal, flesh color.

Coquette des Alps, white and blush.

Coquette des Blanches, white, often blush.

John Hopper, rose and carmine.

Jules Margottin, carmine rose.

Leopold Premier, red and crimson.

La France, silvery rose.

La Reine, rose.

Louis Van Houtte, crimson maroon.

Madam Plantier, white.

Mad. Geo. Bruant, white.

Persian Yellow, bright yellow.

Pierre Notting, deep crimson and violet.

Rugosa Rubra, deep rose with violet.

Soleil d'Or, golden yellow, shaded with deep red.

Ulrich Brunner, cherry red.

Victor Verdier, bright rose with carmine.

Viok's Caprice, pink, striped white and carmine.

\section{ross.}

Countess de Murinais, white, crested red.

Princess Adelaide, pink.

Salot, red.

\section{CI,IMBING.}

Baltimore Belle, white.

Jules Margottin, carmine.

Queen of Prairie, pink.

\section{EVERBL,OOMING TEAS.}

American Beauty, crimson.

Bon Silene, carmine.

Catherine Mermet, pink.

Clothilde Soupert, pearly white.

Duchess of Albany, deep pink.

Gloire de Dijon, salmon.

Hermosa, rose.

Marechal Neil, yellow.

Meteor, rich dark crimson,

Niphetos, white, tinged yellow.

Perle des Jardins, canary.

Papa Gontier, rose, shaded yellow.

Safrano, saff ron and apricot.

Sunset, saffron.

The Bride, pure white.

\section{Best Fruits for the Home Garden.}

We are often asked: "What are the best fruits for my garden?" The following list will answer the question :

Apples (Summer)-Early Harvest, Astrachan, Yel. Trans. (Fall)-Oldenburg, Gravenstein, Maiden's Blush

(Winter)-Baldwin, Nonesuch, King, McIntosh Red,

Spy, Greening, Sutton Beauty, Spitzenburg, Tolman Sweet, Wealthy, Yellow Bellflower.

Pears-Bartlett, Clapp's Favorite, Anjou, Angouleme Kieffer's Hybrid (for canning), Sheldon, Seckel, Lawrence.

Cherries (Dark) - Tartarian, Schmidt's, Windsor. (Light)-Napoleon, Gov. Wood, Spanish. (Sour)-Olivet, Richmond, Montmorency.

Plums (Japan)-Abundance, Burbank.

(Eup.)-Bradshaw, Grand Duke. Lombard, Monarch, Reine Claude, German Prune.

Peaches (Ripening in the order named)-Waterloo, Alexander, Hale's Early, Early Crawford, Elberta, Brigdon, Stump, Crosby, Late Crawford, Stevens" Rareripe, Salway.

Quinces-Orange, Rea's Mammoth, Champion.

Apricots-Early Golden, Moorpark, Montgamet.

Grapes (Black)-Moore's Elarly, Concord, Worden. (Red)-Agawam, Brighton, Delaware, Salem. (White)-Moore's Diamond, Niagara, Pocklington.

Currants (Red)-('herry, LaVersailles, Fay's. Perfection (White)-Grape, White Dutch. (Black)-Lee's Prolific, Champion.

Raspberries (Red)-Columbian, Cuthbert, Marlboro. (Black)-Cumberland, Gregg, Mam. Cluster, Ohio. (Yellow)-Golden Queen.

Blackberries-Rathbun, Agawam, Erie, Wilson Early. Gooseberries-Industry, Downing, Pearl, Columbus. Asparagus-Colossal, Palmetto.

Rhubarb-Myatt's Linnæus, Victoria.

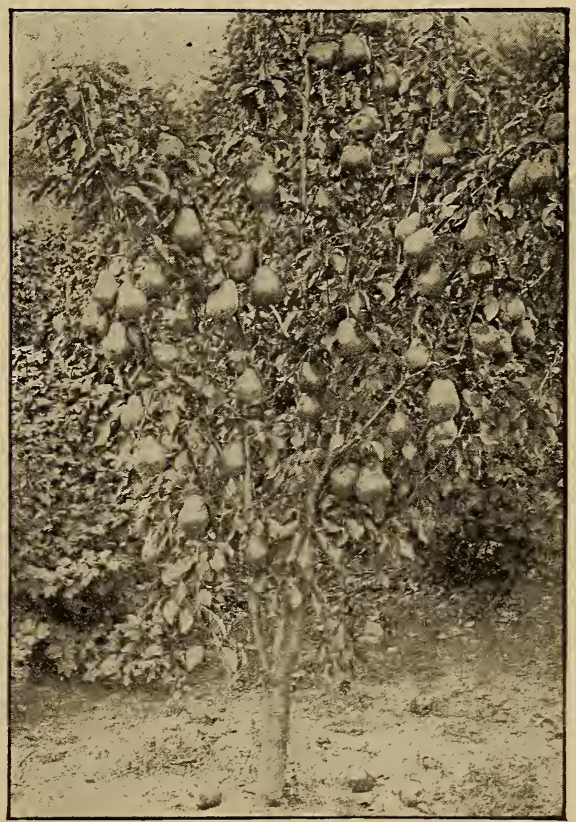

Dwarf Pears. 


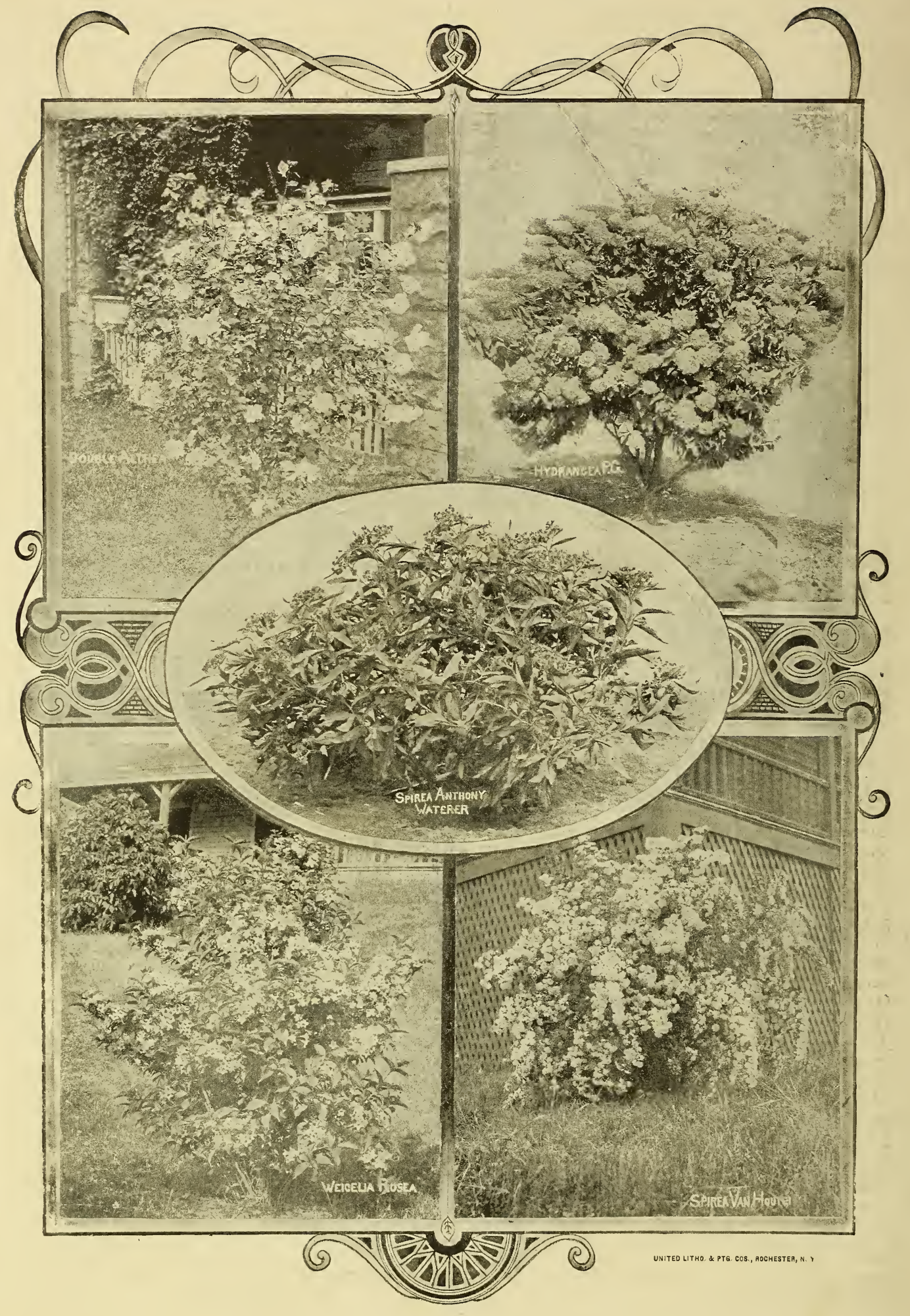

